\title{
The Impact of Green Innovation on a Firm's Value from the Perspective of Enterprise Life Cycles
}

\author{
Deming Dai and Yujia Xue *(1) \\ Renmin Business School, Renmin University of China, Beijing 100872,China; ddm_ruc@163.com \\ * Correspondence: scqtdj@163.com
}

Citation: Dai, D.; Xue, Y. The Impact of Green Innovation on a Firm's

Value from the Perspective of Enterprise Life Cycles. Sustainability 2022, 14, 1226. https://doi.org/ $10.3390 /$ su14031226

Academic Editor: Luigi Aldieri

Received: 14 December 2021

Accepted: 19 January 2022

Published: 21 January 2022

Publisher's Note: MDPI stays neutral with regard to jurisdictional claims in published maps and institutional affiliations.

Copyright: (C) 2022 by the authors. Licensee MDPI, Basel, Switzerland. This article is an open access article distributed under the terms and conditions of the Creative Commons Attribution (CC BY) license (https:// creativecommons.org/licenses/by/ $4.0 /)$.

\begin{abstract}
Many studies focus on the impact of green innovation on enterprises, but few studies pay attention to the difference made by the impact of green innovation at the different stages of a firm's life cycle. This study used Chinese A-share listed companies as a sample to conduct research and found that green innovation has a positive effect on a firm's value. However, compared with firms at a mature stage of their life cycle, the impact of green innovation on firm value is more significant in firms at the stages of growth and decline. Further research shows that green innovation can increase the value of firms at the growth stage by improving their sustainable development capability and reducing debt financing costs. However, for firms at the decline stage of their life cycle, green innovation can only increase firm value by reducing debt financing costs. In addition, the nature of property rights and the level of corporate governance will have a moderating effect on the relationship between green innovation and firm value. This research will not only enrich the previous literature but also guide the allocation of resources for firms at different stages of their life cycle to carry out green innovation.
\end{abstract}

Keywords: green innovation; life cycle; firm value; sustainable development capability; debt financing cost

\section{Introduction}

With the development of the global economy, the contradiction between the socialeconomic system and the ecosystem has become increasingly prominent. The global ecosystem is facing severe challenges, and the environmental problems faced by China are the epitome of the global environmental problem [1]. In these circumstances, how to alleviate the ecological pressure and protect the environment while maintaining rapid economic development has become an important topic and a difficult problem that must be faced in the new century. These days, China attaches great importance to environmental protection. Since the 18th National Congress of the Communist Party of China, its president Xi Jinping has repeatedly emphasized that "Clear waters and green mountains are as valuable as mountains of gold and silver. And we must not sacrifice the ecological environment for temporary economic development". As the mainstay of the Chinese market economy, enterprises are facing the challenges brought by environmental changes while realizing economic growth [2]; they should also take more responsibility for protecting the ecological environment. So how should companies achieve synergy between value creation and environmental protection? In 2016, the State Council issued the "Thirteenth Five-Year Plan for Ecological Environmental Protection". The "Plan" takes "innovation, coordination, [being] green, openness, and sharing" as the development concepts to guide work in the field of the ecological environment. It can be seen that "innovation" and "green" have become important themes in current economic development, and more and more experts and scholars have begun to pay attention to the significance of green innovation $[3,4]$.

However, whether enterprises can realize the synergy between green innovation and economic development is still a major controversy in academia. Some studies believe 
that green innovation helps to improve the financial performance and environmental performance of enterprises [5-7] and it has become an important driving factor for the sustainable development of enterprises [8,9]. However, other studies posit that green innovation has no significant effect on the improvement of the overall financial status and profitability of enterprises [10-12]. Aguilera and Ortiz [10] report that the firm value of enterprises with green innovation is not significantly higher than that of enterprises without green innovation.

Previous studies have several gaps in variable measurement, theoretical analysis, and empirical tests: first, some studies extract key words related to green innovation from the relevant policies or documents of the enterprises through text analysis to measure the green innovation ability of the enterprises. Such a measurement method is inevitably subjective and the comparability between different enterprises is poor. Second, the life cycle of a business is an important perspective when studying the corporate economy. In different life cycles, enterprises may face different problems and make different choices, which will then have different impacts on those enterprises [13]. Innovation is the major driving factor of the sustainable development of enterprises, which may have different impacts on the firm at the different stages of an enterprise's life cycle [14,15], but previous studies seldom pay attention to the impact of the enterprises' innovation behavior on firm value from the perspective of the life cycle. Third, most of the studies use theoretical analysis to explore why green innovation has an impact on the economic development of enterprises. Few studies have conducted empirical tests on the mechanism in this relationship between green innovation and the economic development of enterprises.

Using the green patent data of Chinese A-share-listed companies during 2007-2019, our study intends to examine whether green innovation has an effect on firm value and whether the impact of green innovation is different at different stages of the firm's life cycle, which will cover the research gaps mentioned above. The results show that green innovation has a positive effect on firm value and that the impact of green innovation is different at different stages of a firm's life cycle. Specifically, compared with firms at a mature stage, the green innovation of firms at the stages of growth and decline can have a greater impact on firm value. Further analyses indicate that sustainable development capability and debt-financing costs play important mediation roles in the relationship between green innovation and firm value. What is more, the nature of property rights and corporate governance can moderate the effect of green innovation on firm value.

The contributions of this paper are as follows: first, this paper uses green patent data to measure the green innovation status of enterprises. The measurement method is more objective and enhances comparability between different enterprises, which can cover the research gap via variable measurement. Second, compared with previous studies, this paper is based on the enterprise life-cycle theory and examines the degree of impact of green innovation on firm value at different stages of the enterprise life cycle, which can cover the research gap in theoretical analysis and enrich the enterprise life-cycle theory. Third, this paper not only finds that green innovation has a positive impact on firm value but also tests the mechanism in this relationship, which is a kind of supplement to previous studies and can cover the research gap with an empirical test.

The remainder of this paper is organized as follows. Section 2 presents the literature review and the development of the research hypotheses. Section 3 explains the research method adopted, including variable measurements, model specifications, sample and data collection details, and analysis techniques. Section 4 presents the empirical results along with a discussion. Sections 5 and 6 conclude with a summary of the findings, the implications of the research, and the limitations of the research.

\section{Literature Review and Hypothesis}

\subsection{Green Innovation and Firm Value}

Previous studies have found that management characteristics [16,17], corporate governance level [18], debt-financing ability [19-21], innovation input [22,23], and other factors 
will all have an impact on firm value. Belenzon and Patacconi [24] use the patent data of European companies and the patent data of American companies, respectively, to conduct research, and find that due to differences in the institutional environment and other aspects, when compared with American companies, the technological innovation of European companies has a more significant impact on firm value. Jin et al. [22] find that compared with companies without venture capital holdings, companies with venture capital holdings always receive more external supervision, which makes them pay more attention to their long-term business performance, continuously revise their innovation direction, and improve their innovation efficiency and the firm's value. Innovation is a major contributor to the sustainable development of business and society [25]. The improvement of innovation ability can significantly enhance the competitive advantage of enterprises and improve enterprises' performance and reputation [26-28], which may improve the value of those enterprises. Gallardo-Vázquez et al. [29] propose that innovation has a strong effect on SMEs' competitive success and reputation. Enterprises that develop more innovation practices can achieve significant organizational and financial results. Palacios-Manzano et al. [30] suggest that innovative products and services face less competition when being introduced in the market, enabling the enterprise to increase its profits and differentiate itself from the competition.

So how does green innovation affect firm value? At present, there are still many controversies as to whether green innovation can contribute to the improvement of firm value. Yang et al. [31] propose that when limited by the inherent concept of environmental governance, green innovation in Chinese enterprises has a significant negative impact on firm value. However, Agustia et al. [23] used Indonesia's listed company data to conduct a study and report that the enterprises' green innovation could significantly enhance the enterprises' competitive advantage and have a positive impact on firm value.

We propose that green innovation will have a significantly positive impact on firm value, which is specifically reflected in the following three aspects: first, green innovation can help optimize the organization's production structure, and bring green and environmentally friendly new technologies and new products to the enterprise [32], to produce more differentiated products to enhance the enterprise's competitive advantage. Fernando et al. [33] conducted a study using Malaysian enterprises as a sample, and report that green innovation has improved the production capacity of enterprises and created barriers to entry for potential competitors, thereby enhancing an enterprise's sustainable development capabilities. Second, compared with traditional innovation, green innovation can achieve the effect of environmental protection [34], reduce environmental pressure, and improve the production efficiency of the enterprise [35]. Xie and Zhu [2] find that the green innovation of enterprises can significantly improve their environmental performance and financial performance. Green innovation is an important driving factor to realize the "harmonious symbiosis" of enterprises and the environment. A firm's value is the discounted value of the enterprise's future cash flow. Therefore, the value of the enterprise will be affected by the enterprise's future profitability and sustainable development capabilities [36]. The improvement of enterprise performance and sustainable development capabilities will help improve the enterprise's value. Third, green innovation helps enterprises improve their business image, coordinate the relationship between the enterprise and various stakeholders, and create good external conditions for the economic development of the enterprise. Zhu et al. [37] find that green innovation can help promote the improvement of the corporate environment and can better coordinate the relationship with customers and suppliers. Green innovation can help enterprises to gain more support from stakeholders and reduce their financing costs. The reduction of financing costs and the improvement of financing capabilities help to enhance the value of enterprises [38]. To sum up, green innovation can create competitive advantages for enterprises, enhance enterprises' sustainable development capabilities and reduce enterprises' financing constraints, which may significantly enhance a firm's value. Therefore, we anticipate that green innovation could enhance the value of enterprises, which leads to our first hypothesis: 
Hypothesis 1. Green innovation is positively associated with firm value.

\subsection{Green Innovation, Life Cycle and Firm Value}

The life cycle is an important perspective when studying the value of enterprises. Enterprises at different stages of their life cycle always have different characteristics and face different risks and challenges [13]. For enterprises at the growth stage, in terms of growth ability, they have a strong motivation to gain a competitive advantage in the industry and quickly occupy the market by developing new technologies and new products. At this stage, the profitability of enterprises continues to increase [39]. In terms of cash flow and external financing needs, enterprises at the growth stage usually make large-scale investments and have relatively tight cash flow, which makes enterprises at the growth stage need relatively large-scale external financing to obtain the cash flow required for rapid growth. For enterprises at the growth stage, green innovation can help to enhance enterprises' competitive advantage and sustainable development capacity. What is more, green innovation can also enhance enterprises' external financing ability. The benefits of green innovation can meet the needs of enterprises at the growth stage to rapidly develop technology and expand the market, and significantly alleviate the financing difficulties faced by these enterprises; therefore, the development of green innovation is likely to enhance the value of enterprises when in the growth stage.

For enterprises at the mature stage, in terms of growth ability, these firms have already occupied a certain market for some time and have a relatively stable customer base. Compared with firms at other stages of their life cycle, enterprises at the mature stage have the strongest profitability, but their growth rates have slowed down compared with enterprises at the growth stage. In terms of cash flow and external financing needs, compared with enterprises at the growth stage, enterprises at the mature stage have more stable cash flow, relatively fewer financing constraints, and less demand for external financing [40]. Enterprises at the mature stage have formed on a relatively large scale and are in a relatively stable development stage. The advantages of expanding the market and alleviating financing constraints brought by green innovation are not substantial among these enterprises. Therefore, the possibility for enterprises at the mature stage to improve firm value through green innovation is relatively small.

For enterprises at the stage of decline, in terms of growth ability, these enterprises gradually lose their competitive advantage, which makes their profit-growth space smaller and smaller, and their profitability decreases. In terms of cash flow and external financing needs, enterprises at the stage of decline have relatively large financing constraints and face greater pressure when borrowing and repaying debts [41], which make these enterprises experience relatively tight cash flow and increase their external financing needs. However, the development of green innovation can help to improve their business image and let them gain more support from stakeholders, which can reduce their financing costs. The reduction in financing costs can help to enhance the value of enterprises [38]. Therefore, the development of green innovation is likely to enhance the value of enterprises when at the stage of decline.

In general, on the one hand, compared with enterprises at the mature stage, enterprises at the growth stage have a stronger motivation to achieve sustainable growth; on the other hand, compared with enterprises at the mature stage, enterprises at the growth stage and enterprises at the decline stage face higher pressure regarding external financing. Therefore, we anticipate that compared with enterprises at the mature stage, the development of green innovation may play a greater positive role in enterprises at the stages of growth or decline, which leads to our second hypothesis:

Hypothesis 2. The impact of green innovation on firm value may be different in enterprises at different stages of their life cycle. Compared with enterprises at a mature stage, green innovation has a greater positive impact on firm value in enterprises at the stages of growth or decline. 


\section{Research Design}

\subsection{Variables Selection}

\subsubsection{Firm Value}

We used Tobin's $Q$ ratio to measure the value of an enterprise. Tobin's $Q$ ratio is the enterprise's market value, divided by the enterprise's total assets at the end of the period.

\subsubsection{Green Innovation}

We measured an enterprise's green innovation level based on the number of green patent applications made by that enterprise. Specifically, the green innovation level is the natural logarithm of the number of that enterprise's green patent applications, plus one.

\subsubsection{Enterprise Life Cycle}

Based on the research method of Dickinson [42], we adopted the enterprise cash flow analysis method to measure the life cycle of an enterprise. The life cycle of an enterprise is divided into a start-up stage, a growth stage, a mature stage, and a decline stage. Following the method of Hou et al. [43], because the sample selected in this paper is listed companies, it can be assumed that these companies have passed the start-up stage. Thus, we combined the samples in the start-up stage with the samples in the growth stage and collectively refer to these samples as the samples in the growth stage. The method of cash flow analysis is shown in Table 1. Those samples with negative cash flow from investment activities and positive cash flow from financing activities were defined as samples in the growth stage; the samples with positive cash flow from operating activities and negative cash flow from investment and financing activities were defined as samples in the mature stage; other samples were defined as samples in the decline stage.

Table 1. Definition of the enterprise life cycle.

\begin{tabular}{cccc}
\hline Life Cycle & $\begin{array}{c}\text { Net Cash Flow from } \\
\text { Operating Activities }\end{array}$ & $\begin{array}{c}\text { Net Cash Flow from } \\
\text { Investment Activities }\end{array}$ & $\begin{array}{c}\text { Net Cash Flow from } \\
\text { Financing Activities }\end{array}$ \\
\hline Start-up stage & - & - & + \\
Growth stage & + & - & + \\
Mature stage & + & - & - \\
Decline stage & - & + & $+(-)$ \\
Decline stage & - & - & - \\
Decline stage & + & + & + \\
Decline stage & + & + & - \\
\hline
\end{tabular}

\subsubsection{Sustainable Development Capability}

Following the methods of Yang et al. [44] and Jin [45], we defined sustainable development capability (SUS) as (return on net assets $\times$ retained earnings ratio) $/(1-$ return on net assets $\times$ retained earnings ratio).

\subsubsection{Debt Financing Cost}

Following the methods of Pittman and Fortin [46] and Zhou et al. [47], we defined the enterprise's debt-financing cost (DEBTCOST) as the interest expense divided by the total long-term and short-term debt.

\subsubsection{Other Control Variables}

This paper refers to the research of Jia et al. [48] regarding the following control variables, which may also have an impact on firm value: the firm's size (SIZE), return on assets (ROA), asset-liability ratio (LEV), the growth ability of the firm (GROWTH), the holding percentage of the largest shareholder (FIRST), the dual role of the board chairman (DUAL), the firm's age (AGE), and the nature of property rights (STATE). In addition, the year and industry fixed effects are also controlled, and company-level clustering standard 
errors are used for the model. The specific definition of each variable in this paper is shown in Table 2.

Table 2. Definitions of the variables.

\begin{tabular}{|c|c|}
\hline Variable & Definition \\
\hline \multicolumn{2}{|r|}{ Panel A: Firm value } \\
\hline VALUE & Firm value: the enterprise's market value divided by the enterprise's total assets at the end of the period \\
\hline \multicolumn{2}{|r|}{ Panel B: Green innovation and enterprise life cycle } \\
\hline $\begin{array}{l}\text { GREEN } \\
\text { Life cycle }\end{array}$ & $\begin{array}{c}\text { Green innovation value: the natural logarithm of the number of the enterprise's green patent applications, plus one } \\
\text { The specific definition of the enterprise life cycle, as shown in Table } 1\end{array}$ \\
\hline \multicolumn{2}{|r|}{ Panel C: Control variables } \\
\hline SIZE & The firm's size: the natural logarithm of the firm's total assets \\
\hline $\mathrm{ROA}$ & Return on assets: the firm's net profit, divided by its total assets \\
\hline LEV & Asset-liability ratio: the firm's total liabilities, divided by its total assets \\
\hline GROWTH & The growth ability of the firm: the growth of total revenue in the current period, divided by the total revenue of the previous period \\
\hline FIRST & $\begin{array}{c}\text { The holding percentage of the largest shareholder: the number of shares held by the largest shareholder, divided by the total number of shares of } \\
\text { the enterprise }\end{array}$ \\
\hline DUAL & Dual role of the board chairman: an indicator variable equal to 1 if the board chairman of the firm is also the CEO, and 0 otherwise \\
\hline AGE & The firm's age: the natural logarithm of the firm's listing years, plus one \\
\hline STATE & The nature of property rights: an indicator variable, equal to 1 if the firm is a state-owned enterprise, and 0 otherwise \\
\hline \multicolumn{2}{|r|}{ Panel D: Variables in further analysis } \\
\hline SUS & Sustainable development capability: (return on net assets $\times$ retained earnings ratio) $/(1-$ return on net assets $\times$ retained earnings ratio) \\
\hline DEBTCOST & Debt financing cost: interest expense/total long-term and short-term debt \\
\hline CGI & $\begin{array}{c}\text { Corporate governance index (CGI): the sum of } 14 \text { internal governance factors. The specific definitions of } 14 \text { internal governance factors are } \\
\text { shown in Appendix A. }\end{array}$ \\
\hline \multicolumn{2}{|r|}{ Panel E: Variables in robustness tests } \\
\hline VALUE2 & Enterprise market value/(total assets - net intangible assets - net goodwill) \\
\hline GREEN_mean & Industry average of green innovation (excludes the firm itself) \\
\hline DUMMY & DUMMY $=1$ if green innovation in the sample is not a missing value, and 0 otherwise \\
\hline
\end{tabular}

\subsection{Research Model}

In order to test Hypothesis 1 in this paper, a regression model (1) was constructed. The explained variable in model (1) is the firm value (VALUE), the main explanatory variable in model (1) is green innovation (GREEN), and $\beta_{1}$ is expected to be significantly positive; that is, green innovation has a positive role in promoting firm value. In order to test Hypothesis 2 in this paper, we conducted a sub-sample test of model (1) to test the different effects of green innovation on firm value in different samples at different stages of the life cycle.

$$
\text { VALUE }=\beta_{0}+\beta_{1} \text { GREEN }+ \text { Control }+ \text { YEAR FE }+ \text { INDUSTRY FE }+\varepsilon_{i, t}
$$

We further tested the mediation effect of sustainable development capability and debtfinancing cost. In order to test the mediation effect of sustainable development capability, we referred to the three-step method regarding mediation effect proposed by Wen et al. [49], and constructed the following regression model:

$$
\begin{gathered}
\text { SUS }=\alpha_{0}+\alpha_{1} \text { GREEN }+ \text { Control }+ \text { YEAR FE }+ \text { INDUSTRY FE }+\varepsilon_{i, t} \\
\text { VALUE }=\lambda_{0}+\lambda_{1} \text { GREEN }+\lambda_{2} \text { SUS }+ \text { Control }+ \text { YEAR FE }+ \text { INDUSTRY FE }+\varepsilon_{i, t}
\end{gathered}
$$

The first step of the process is using model (1) to test whether $\beta_{1}$ is significant. If $\beta_{1}$ is significant, it indicates that the total effect of green innovation on the firm value exists. The next step can then be carried out. If $\beta_{1}$ is not significant, it indicates that the total effect does not exist, and further steps should be stopped. The second step involves using model (2) and model (3) to test the significance of $\alpha_{1}$ and $\lambda_{2}$. If any of the two coefficients are not significant, a Sobel test is required. The null hypothesis of the Sobel test is as follows. The indirect effect $\left(\alpha_{1} \times \lambda_{2}\right)$ equals zero. The critical ratio, $Z$, equals $\left(\alpha_{1} \times \lambda_{2}\right)$ divided by the standard error of indirect effect $\left(s_{\alpha_{1 \lambda_{2}}}\right)$. If the test result can disprove the null hypothesis, then the sustainable development capacity has a partial mediation effect. If the test result cannot disprove the null hypothesis, then the sustainable development capacity does not have a mediating effect. If both $\alpha_{1}$ and $\lambda_{2}$ are significant, this indicates 
that the sustainable development capacity has a mediating effect, and the significance of $\lambda_{1}$ can be further tested. In the third step, if $\lambda_{1}$ is significant, this means that the sustainable development capacity has a partial mediation effect. If $\lambda_{1}$ is not significant, this means that the sustainable development capacity has a completely mediating effect.

In order to test the mediation effect of debt-financing cost, we also referred to the threestep method of mediation effect proposed by Wen et al. [49], and construct the following regression model:

$$
\begin{gathered}
\text { DEBTCOST }=\gamma_{0}+\gamma_{1} \text { GREEN }+ \text { Control }+ \text { YEAR FE }+ \text { INDUSTRY FE }+\varepsilon_{i, t} \\
\text { VALUE }=\mu_{0}+\mu_{1} \text { GREEN }+\mu_{2} \text { DEBTCOST }+ \text { Control }+ \text { YEAR FE }+ \text { INDUSTRY FE }+\varepsilon_{i, t}
\end{gathered}
$$

The first step is the same as shown above. The second step involves using model (4) and model (5) to test the significance of $\gamma_{1}$ and $\mu_{2}$. If any of the two coefficients is not significant, a Sobel test is required. If both $\gamma_{1}$ and $\mu_{2}$ are significant, this indicates that the enterprise's debt-financing cost has a mediating effect, and the significance of $\mu_{1}$ can be further tested. In the third step, if $\mu_{1}$ is significant, this means that the enterprise's debt-financing cost has a partial mediation effect. If $\mu_{1}$ is not significant, this means that the enterprise's debt-financing cost has a completely mediating effect.

\subsection{Sample Selection and Data Sources}

We included all A-share-listed firms on the Shanghai and Shenzhen Stock Exchanges during 2007-2019 in our sample. The sample selection process was as follows: (1) following the method of $\mathrm{Wu}$ et al. [50], we excluded the observations for special-treatment firms in imminent danger of delisting during the sample period; (2) we excluded the observations for listed companies in the financial industry (based on the two digits of the CSRC industry code from J66 to J69); and (3) we excluded the observations with missing data. Consequently, the final sample contained 9438 firm-year observations. We sourced the financial data from the China Stock Market and the Accounting Research database. We sourced green innovation data from Chinese Research Data Services. To solve the problem of extreme outliers, we winsorized all continuous variables at the 1st and 99th percentiles.

\subsection{Analysis Techniques}

We used STATA16, a statistical analysis software, to test the regression models in this paper. We used the ordinary least squares (OLS) method to test the impact of green innovation on firm value at different stages of the life cycle. Following the procedure of Wen et al. [49], we used the three-step method to test the mediation effect of sustainable development capability and debt-financing cost. We also used the OLS method to test the moderating effect of the nature of property rights and corporate governance. Considering that the endogeneity problem might arise when examining the relationship between green innovation and firm value, we employed the two-stage least squares (2SLS) method and Heckman two-stage model to address the endogeneity issues.

\section{Empirical Results}

\subsection{Descriptive Statistics}

Table 3 shows the descriptive statistical results of the variables. The minimum value of firm value (VALUE) is 0.89 , the maximum value of firm value is 8.37 , the median value (1.57) is close to the mean value (1.89), and the sample is normally distributed. The minimum value of green innovation (GREEN) is 0 , the maximum value of green innovation is 4.96 , and the mean value of green innovation is 1.55 . There is a relatively large gap in the level of green innovation among different enterprises. The descriptive statistics of other variables are similar to previous studies. 
Table 3. Summary statistics.

\begin{tabular}{ccccccc}
\hline VarName & Obs & Mean & SD & Min & Median & Max \\
\hline VALUE & 9438 & 1.89 & 0.90 & 0.89 & 1.57 & 8.37 \\
GREEN & 9438 & 1.55 & 0.10 & 0.00 & 1.39 & 4.96 \\
SIZE & 9438 & 22.43 & 1.22 & 19.49 & 22.28 & 26.03 \\
ROA & 9438 & 0.04 & 0.05 & -0.24 & 0.04 & 0.21 \\
LEV & 9438 & 0.45 & 0.19 & 0.05 & 0.45 & 0.97 \\
GROWTH & 9438 & 0.18 & 0.32 & -0.53 & 0.13 & 2.61 \\
FIRST & 9438 & 0.35 & 0.14 & 0.09 & 0.33 & 0.75 \\
DUAL & 9438 & 0.25 & 0.43 & 0.00 & 0.00 & 1.00 \\
AGE & 9438 & 2.28 & 0.64 & 0.69 & 2.30 & 3.43 \\
STATE & 9438 & 0.42 & 0.49 & 0.00 & 0.00 & 1.00 \\
\hline
\end{tabular}

\subsection{Analysis of Regression Results}

Table 4 shows the empirical results of model (1). Column (1) is the full-sample regression result. The correlation coefficient between green innovation and firm value is 0.032 , and it is significant at the $1 \%$ level, indicating that green innovation can have a significantly positive effect on firm value, which verifies Hypothesis 1 in this paper. Columns (2)-(4) are the regression results of the sub-samples. In the growth stage and decline stage samples, the correlation coefficients between green innovation and firm value are 0.037 and 0.061 , respectively, and are significant at the $1 \%$ level. However, for enterprises at a mature stage, the correlation coefficient between green innovation and firm value is 0.017 and it is not significant. These results show that green innovation can have a greater impact on firm value in enterprises at the stages of growth and decline rather than those at the mature stage, which verifies Hypothesis 2 in this paper.

Table 4. Green innovation, life cycle and firm value.

\begin{tabular}{|c|c|c|c|c|}
\hline & $\begin{array}{c}\text { (1) } \\
\text { VALUE } \\
\text { Full Sample }\end{array}$ & $\begin{array}{c}\text { (2) } \\
\text { VALUE } \\
\text { Growth Stage }\end{array}$ & $\begin{array}{c}(3) \\
\text { VALUE } \\
\text { Mature Stage }\end{array}$ & $\begin{array}{c}(4) \\
\text { VALUE } \\
\text { Decline Stage }\end{array}$ \\
\hline GREEN & $\begin{array}{c}0.032 * * * \\
(2.61)\end{array}$ & $\begin{array}{c}0.037^{* * *} \\
(2.58)\end{array}$ & $\begin{array}{l}0.017 \\
(0.88)\end{array}$ & $\begin{array}{c}0.061^{* * *} \\
(2.69)\end{array}$ \\
\hline SIZE & $\begin{array}{c}-0.354^{* * *} \\
(-20.78)\end{array}$ & $\begin{array}{c}-0.324^{* * *} \\
(-18.29)\end{array}$ & $\begin{array}{c}-0.347^{* * *} \\
(-15.16)\end{array}$ & $\begin{array}{c}-0.483^{* * *} \\
(-19.65)\end{array}$ \\
\hline $\mathrm{ROA}$ & $\begin{array}{c}4.938^{* * *} \\
(13.16)\end{array}$ & $\begin{array}{c}5.275^{* * *} \\
(10.00)\end{array}$ & $\begin{array}{c}5.523^{* * *} \\
(9.82)\end{array}$ & $\begin{array}{c}3.709 * * * \\
(8.32)\end{array}$ \\
\hline LEV & $\begin{array}{l}-0.212^{* *} \\
(-2.46)\end{array}$ & $\begin{array}{l}-0.241^{* *} \\
(-2.19)\end{array}$ & $\begin{array}{l}-0.141 \\
(-1.13)\end{array}$ & $\begin{array}{l}-0.292^{* *} \\
(-2.09)\end{array}$ \\
\hline GROWTH & $\begin{array}{c}0.055 * \\
(1.93)\end{array}$ & $\begin{array}{c}0.082 * * \\
(2.43)\end{array}$ & $\begin{array}{l}0.006 \\
(0.10)\end{array}$ & $\begin{array}{l}-0.013 \\
(-0.19)\end{array}$ \\
\hline FIRST & $\begin{array}{l}0.013 \\
(0.13)\end{array}$ & $\begin{array}{l}0.137 \\
(1.20)\end{array}$ & $\begin{array}{l}-0.235 \text { * } \\
(-1.74)\end{array}$ & $\begin{array}{l}0.286^{*} \\
(1.83)\end{array}$ \\
\hline DUAL & $\begin{array}{l}0.024 \\
(0.81)\end{array}$ & $\begin{array}{l}0.033 \\
(0.95)\end{array}$ & $\begin{array}{l}0.026 \\
(0.56)\end{array}$ & $\begin{array}{l}-0.037 \\
(-0.73)\end{array}$ \\
\hline AGE & $\begin{array}{c}0.241^{* * * *} \\
(8.84)\end{array}$ & $\begin{array}{c}0.239 * * * \\
(7.87)\end{array}$ & $\begin{array}{c}0.195^{* * *} \\
(5.25)\end{array}$ & $\begin{array}{c}0.337 * * * \\
(8.19)\end{array}$ \\
\hline STATE & $\begin{array}{l}0.016 \\
(0.43)\end{array}$ & $\begin{array}{l}0.018 \\
(0.41)\end{array}$ & $\begin{array}{l}0.053 \\
(1.09)\end{array}$ & $\begin{array}{l}-0.014 \\
(-0.26)\end{array}$ \\
\hline _cons & $\begin{array}{c}8.667 * * * \\
(25.67)\end{array}$ & $\begin{array}{c}8.222 * * * \\
(21.98)\end{array}$ & $\begin{array}{c}8.454^{* * *} \\
(18.17)\end{array}$ & $\begin{array}{c}10.730 * * * \\
(19.89)\end{array}$ \\
\hline $\begin{array}{c}\text { YEAR } \\
\text { INDUSTRY }\end{array}$ & $\begin{array}{l}\text { control } \\
\text { control }\end{array}$ & $\begin{array}{l}\text { control } \\
\text { control }\end{array}$ & $\begin{array}{l}\text { control } \\
\text { control }\end{array}$ & $\begin{array}{l}\text { control } \\
\text { control }\end{array}$ \\
\hline $\begin{array}{c}\mathrm{N} \\
\text { adj. } \mathrm{R}^{2}\end{array}$ & $\begin{array}{c}9438 \\
0.3925\end{array}$ & $\begin{array}{c}4621 \\
0.4057\end{array}$ & $\begin{array}{c}3344 \\
0.3753\end{array}$ & $\begin{array}{c}1473 \\
0.4344\end{array}$ \\
\hline
\end{tabular}

Notes: The first row represents the estimated coefficient; the second row represents the $t$-value of significance. $*^{* *}$, and ${ }^{* * *}$ indicate statistical significance at $p<0.10,0.05$, and 0.01 , respectively. 


\subsection{Further Analysis}

\subsubsection{The Mediation Effect of Sustainable Development Capacity}

As mentioned above, on the one hand, green innovation can enhance an enterprise's competitive advantage [33] and increase its production efficiency [35], thereby enhancing its sustainable development capability; on the other hand, green innovation can improve an enterprise's organizational environment and coordinate the relationship between the enterprise and various stakeholders, thereby reducing financing costs and alleviating the financing pressure of the enterprise. Therefore, we propose that green innovation can enhance the value of an enterprise by improving an enterprise's sustainable development capability and reducing the enterprise's debt-financing costs.

We first used models (1)-(3) to test the mediation effect of sustainable development capability. The regression results of the first step are shown in Table 4. In the full sample, the growth stage sample, and the decline stage sample, the correlation coefficients of green innovation and firm value were significantly positive at the $1 \%$ level. However, in the mature-stage sample, the correlation coefficient of green innovation and firm value was not significant. Therefore, we stopped testing the mature-stage sample and continued testing other samples. The regression results of the second and third steps are shown in Table 5. Columns (1) and (2) show the empirical results of the full sample, columns (3) and (4) show the empirical results of the growth stage sample, and columns (5) and (6) show the empirical results of the decline stage sample. In the full sample and the growth-stage sample, the coefficients of $\alpha_{1}, \lambda_{1}$, and $\lambda_{2}$ were all significantly positive at the $1 \%$ level, but in the decline-stage sample, the coefficient of $\alpha_{1}$ was not significant, which showed that the sustainable development capacity has a partial mediation effect; green innovation can enhance a firm's value by improving the enterprise's sustainable development capacity, but this partial mediation effect only exists in the enterprises at the growth stage, that is, green innovation is unlikely to improve the sustainable development capability of the enterprises at the decline stage. This result is consistent with the life-cycle theory of enterprises. Compared with enterprises in other life-cycle stages, the profitability of enterprises at the decline stage decreases, and the space for further development becomes smaller and smaller. It is difficult for enterprises at the decline stage to improve their sustainable development capacity through green innovation.

\subsubsection{The Mediation Effect of Debt-Financing Costs}

So how does green innovation increase the value of enterprises at the decline stage? We propose that green innovation can reduce the cost of the debt-financing of enterprises, and the reduction of financing costs will help alleviate the external financing pressure of enterprises, thereby enhancing the value of enterprises [39,51].

We used models (1), (4) and (5) to test the mediation effect of the debt-financing cost. The regression results of the second and third steps are shown in Table 6. Columns (1) and (2) show the empirical results of the full sample, columns (3) and (4) show the empirical results of the samples at the growth stage, and columns (5) and (6) show the empirical results of the samples at the decline stage. In all samples, the coefficients of $\gamma_{1}$ and $\mu_{2}$ were significantly negative, which shows that the enterprise's debt financing cost did have a mediation effect. Green innovation can increase the value of the enterprise by reducing the enterprise's debt financing cost. What is more, it is worth noting that in the samples at the growth stage, the coefficient of $\mu_{1}$ was significantly positive, indicating that the enterprise's debt-financing costs had a partial mediation effect in the correlation between green innovation and firm value in enterprises at the growth stage; but in the samples at the decline stage, the coefficient of $\mu_{1}$ was not significant, indicating that the enterprise's debt-financing cost had a completely mediating effect in the correlation between green innovation and firm value in enterprises at the decline stage. 
Table 5. The mediation effect of sustainable development capacity.

\begin{tabular}{|c|c|c|c|c|c|c|}
\hline & $\begin{array}{c}\text { (1) } \\
\text { SUS } \\
\text { Full Sample }\end{array}$ & $\begin{array}{c}(2) \\
\text { VALUE } \\
\text { Full Sample }\end{array}$ & $\begin{array}{c}\text { (3) } \\
\text { SUS } \\
\text { Growth Stage }\end{array}$ & $\begin{array}{c}(4) \\
\text { VALUE } \\
\text { Growth Stage }\end{array}$ & $\begin{array}{c}\text { (5) } \\
\text { SUS } \\
\text { Decline Stage }\end{array}$ & $\begin{array}{c}\text { (6) } \\
\text { VALUE } \\
\text { Decline Stage }\end{array}$ \\
\hline GREEN & $\begin{array}{c}0.001 * * * \\
(3.63)\end{array}$ & $\begin{array}{c}0.032 * * * \\
(3.68)\end{array}$ & $\begin{array}{c}0.002^{* * *} \\
(3.43)\end{array}$ & $\begin{array}{c}0.033^{* * *} \\
(2.78)\end{array}$ & $\begin{array}{l}0.002 \\
(1.22)\end{array}$ & $\begin{array}{c}0.060^{* *} \\
(2.42)\end{array}$ \\
\hline SUS & & $\begin{array}{c}2.006^{* * *} \\
(8.94)\end{array}$ & & $\begin{array}{c}2.874^{* * *} \\
(8.57)\end{array}$ & & $\begin{array}{l}0.536 \\
(0.85)\end{array}$ \\
\hline SIZE & $\begin{array}{c}-0.002 * * * \\
(-4.38)\end{array}$ & $\begin{array}{c}-0.356^{* * *} \\
(-36.39)\end{array}$ & $\begin{array}{c}-0.001^{* *} \\
(-2.24)\end{array}$ & $\begin{array}{c}-0.323^{* * *} \\
(-24.23)\end{array}$ & $\begin{array}{c}-0.002 \\
(-1.41)\end{array}$ & $\begin{array}{c}-0.495^{* * *} \\
(-11.68)\end{array}$ \\
\hline ROA & $\begin{array}{l}1.227 * * * \\
(117.53)\end{array}$ & $\begin{array}{c}4.176^{* * *} \\
(11.75)\end{array}$ & $\begin{array}{c}1.373 * * * \\
(87.74)\end{array}$ & $\begin{array}{c}3.267 * * * \\
(5.60)\end{array}$ & $\begin{array}{c}1.137^{* * *} \\
(17.75)\end{array}$ & $\begin{array}{c}4.817^{* * *} \\
(4.52)\end{array}$ \\
\hline LEV & $\begin{array}{c}0.125 * * * \\
(45.71)\end{array}$ & $\begin{array}{c}-0.361 \text { *** } \\
(-5.47)\end{array}$ & $\begin{array}{c}0.125 * * * \\
(33.23)\end{array}$ & $\begin{array}{c}-0.550 * * * \\
(-5.74)\end{array}$ & $\begin{array}{c}0.108^{* * *} \\
(12.17)\end{array}$ & $\begin{array}{l}-0.308 \\
(-1.64)\end{array}$ \\
\hline GROWTH & $\begin{array}{c}0.013^{* * *} \\
(10.21)\end{array}$ & $\begin{array}{l}0.029 \\
(1.08)\end{array}$ & $\begin{array}{c}0.010^{* * *} \\
(6.98)\end{array}$ & $\begin{array}{l}0.039 \\
(1.17)\end{array}$ & $\begin{array}{c}0.011^{* * *} \\
(3.33)\end{array}$ & $\begin{array}{l}-0.018 \\
(-0.25)\end{array}$ \\
\hline FIRST & $\begin{array}{c}-0.009^{* * *} \\
(-3.31)\end{array}$ & $\begin{array}{l}0.030 \\
(0.50)\end{array}$ & $\begin{array}{l}-0.005 \\
(-1.32)\end{array}$ & $\begin{array}{c}0.164 \text { * } \\
(1.92)\end{array}$ & $\begin{array}{c}-0.012 \\
(-1.59)\end{array}$ & $\begin{array}{l}0.341 \\
(1.58)\end{array}$ \\
\hline DUAL & $\begin{array}{c}0.002^{* * *} \\
(2.60)\end{array}$ & $\begin{array}{l}0.019 \\
(0.96)\end{array}$ & $\begin{array}{l}0.001 \\
(0.93)\end{array}$ & $\begin{array}{l}0.019 \\
(0.72)\end{array}$ & $\begin{array}{l}0.002 \\
(0.68)\end{array}$ & $\begin{array}{l}-0.033 \\
(-0.58)\end{array}$ \\
\hline AGE & $\begin{array}{c}0.003 * * * \\
(4.06)\end{array}$ & $\begin{array}{c}0.234^{* * *} \\
(14.23)\end{array}$ & $\begin{array}{c}0.003 * * * \\
(3.27)\end{array}$ & $\begin{array}{c}0.229^{* * *} \\
(10.19)\end{array}$ & $\begin{array}{c}0.006^{* * *} \\
(3.20)\end{array}$ & $\begin{array}{c}0.357^{* * *} \\
(5.74)\end{array}$ \\
\hline STATE & $\begin{array}{l}0.000 \\
(0.11)\end{array}$ & $\begin{array}{l}0.024 \\
(1.11)\end{array}$ & $\begin{array}{c}-0.005^{* * *} \\
(-3.76)\end{array}$ & $\begin{array}{l}0.052 * \\
(1.78)\end{array}$ & $\begin{array}{l}-0.001 \\
(-0.28)\end{array}$ & $\begin{array}{l}-0.020 \\
(-0.26)\end{array}$ \\
\hline _cons & $\begin{array}{l}0.010 \\
(0.99)\end{array}$ & $\begin{array}{c}8.635^{* * *} \\
(41.16)\end{array}$ & $\begin{array}{l}-0.016 \\
(-1.28)\end{array}$ & $\begin{array}{c}8.156^{* * *} \\
(28.33)\end{array}$ & $\begin{array}{l}0.011 \\
(0.37)\end{array}$ & $\begin{array}{c}10.809^{* * *} \\
(14.49)\end{array}$ \\
\hline $\begin{array}{c}\text { YEAR } \\
\text { INDUSTRY }\end{array}$ & $\begin{array}{l}\text { control } \\
\text { control }\end{array}$ & $\begin{array}{l}\text { control } \\
\text { control }\end{array}$ & $\begin{array}{l}\text { control } \\
\text { control }\end{array}$ & $\begin{array}{l}\text { control } \\
\text { control }\end{array}$ & $\begin{array}{l}\text { control } \\
\text { control }\end{array}$ & $\begin{array}{l}\text { control } \\
\text { control }\end{array}$ \\
\hline $\begin{array}{c}\mathrm{N} \\
\text { adj. } \mathrm{R}^{2}\end{array}$ & $\begin{array}{c}9239 \\
0.6420\end{array}$ & $\begin{array}{c}8914 \\
0.4160\end{array}$ & $\begin{array}{c}4531 \\
0.6777\end{array}$ & $\begin{array}{c}4384 \\
0.4316\end{array}$ & $\begin{array}{c}1431 \\
0.6290\end{array}$ & $\begin{array}{c}1363 \\
0.4576\end{array}$ \\
\hline
\end{tabular}

Notes: The first row represents the estimated coefficient; the second row represents the $t$-value of significance. $*, * *$, and ${ }^{* * *}$ indicate statistical significance at $p<0.10,0.05$, and 0.01 , respectively.

The result of the mediation effect test is consistent with the life-cycle theory of enterprise. For enterprises at the growth stage, they not only need to enhance the competitive advantage and realize the continuous growth of profit but also face the greater pressure of external financing. The improvement of green innovation can directly help enterprises to achieve sustainable growth while reducing the pressure on external financing, thereby enhancing the firm's value. However, for enterprises at the decline stage, their profit margins are getting smaller and smaller, and their ability to develop continuously decreases. Compared with the needs of sustainable development, enterprises at the decline stage urgently need to alleviate the pressure on external financing. The improvement of green innovation can coordinate the relationship between enterprises and stakeholders, help enterprises to establish a good reputation, and ease the financing pressure of enterprises at the decline stage, which can enhance the firm's value.

\subsubsection{The Moderating Effect of Property Rights}

Previous studies have found that innovation plays a different role in enterprises with different property rights [52]. Therefore, we are going to examine whether property rights have a moderating effect on the correlation between green innovation and a firm's value. The moderating effect of the nature of property rights may be reflected in the following three aspects: first, compared with private enterprises, state-owned enterprises may value their social status more than the rapid growth of financial performance, and pay more attention to the stability of their external environment [20]. Therefore, state-owned enterprises have less incentive to create an enterprise value increment through innovation. Second, compared with private enterprises, the innovation decision-making of state-owned enterprises will be subject to more government intervention [25], and their green innovation behavior may contain more political motivations rather than the purpose of maximizing the firm's value. Therefore, compared with state-owned enterprises, green innovation behaviors are more likely to enhance the profitability and development potential of private enterprises, thereby enhancing a firm's value. Third, there is a big difference between the financing constraints of state-owned enterprises and private enterprises in China. Financial institutions in China prefer state-owned enterprises, and private enterprises are more vulnerable to credit discrimination, exerting greater external financing pressures on private 
enterprises [53]. Therefore, compared with state-owned enterprises, private enterprises are more likely to use green innovation to relieve financing pressures, and then enhance the firm's value. From the findings mentioned above, we propose that property rights can have a moderating effect on the correlation between green innovation and a firm's value. Table 7 reports the empirical results of the moderating effect of the nature of property rights. Columns (1), (3) and (5) show the empirical results of state-owned enterprise samples; columns (2), (4) and (6) show the empirical results of private enterprise samples. The empirical results show that in the sample of private enterprises, the correlation coefficients of green innovation and firm value were significantly positive at the level of $1 \%$ or $5 \%$. However, in the sample of state-owned enterprises, the correlation coefficients of green innovation and firm value were not significant, indicating that compared with state-owned enterprises, green innovation in private enterprises will have a more significant impact on a firm's value.

Table 6. The mediation effect of debt-financing costs.

\begin{tabular}{|c|c|c|c|c|c|c|}
\hline & $\begin{array}{c}\text { (1) } \\
\text { DEBTCOST } \\
\text { Full Sample }\end{array}$ & $\begin{array}{c}(2) \\
\text { VALUE } \\
\text { Full Sample }\end{array}$ & $\begin{array}{c}\text { (3) } \\
\text { DEBTCOST } \\
\text { Growth Stage }\end{array}$ & $\begin{array}{c}\text { (4) } \\
\text { VALUE } \\
\text { Growth Stage }\end{array}$ & $\begin{array}{c}\text { (5) } \\
\text { DEBTCOST } \\
\text { Decline Stage }\end{array}$ & $\begin{array}{c}\text { (6) } \\
\text { VALUE } \\
\text { Decline Stage }\end{array}$ \\
\hline GREEN & $\begin{array}{c}-0.002^{* * *} \\
(-8.84)\end{array}$ & $\begin{array}{c}0.032 * * * \\
(3.57)\end{array}$ & $\begin{array}{c}-0.001^{* * *} \\
(-5.47)\end{array}$ & $\begin{array}{c}0.036^{* * *} \\
(3.08)\end{array}$ & $\begin{array}{c}-0.003 * * * \\
(-3.98)\end{array}$ & $\begin{array}{l}0.038 \\
(1.60)\end{array}$ \\
\hline DEBTCOST & & $\begin{array}{c}-0.899 * * \\
(-2.39)\end{array}$ & & $\begin{array}{l}-1.243 \\
(-1.88)\end{array}$ & & $\begin{array}{l}-1.580 * \\
(-1.87)\end{array}$ \\
\hline SIZE & $\begin{array}{l}0.001 \text { * } \\
(1.92)\end{array}$ & $\begin{array}{c}-0.372 * * * \\
(-38.16)\end{array}$ & $\begin{array}{l}-0.000 \\
(-0.22)\end{array}$ & $\begin{array}{c}-0.339 * * * \\
(-25.45)\end{array}$ & $\begin{array}{l}0.001 \\
(1.55)\end{array}$ & $\begin{array}{c}-0.505^{* * *} \\
(-19.38)\end{array}$ \\
\hline ROA & $\begin{array}{c}-0.047^{* * *} \\
(-8.72)\end{array}$ & $\begin{array}{c}4.851^{* * *} \\
(24.53)\end{array}$ & $\begin{array}{c}-0.053 * * * \\
(-7.80)\end{array}$ & $\begin{array}{c}5.249 * * * \\
(17.16)\end{array}$ & $\begin{array}{l}-0.020 \\
(-1.41)\end{array}$ & $\begin{array}{c}3.641^{* * *} \\
(8.01)\end{array}$ \\
\hline LEV & $\begin{array}{c}0.069^{* * *} \\
(43.22)\end{array}$ & $\begin{array}{c}-0.152^{* *} \\
(-2.35)\end{array}$ & $\begin{array}{c}0.049^{* * *} \\
(25.92)\end{array}$ & $\begin{array}{l}-0.170 * \\
(-1.88)\end{array}$ & $\begin{array}{c}0.084^{* * *} \\
(18.83)\end{array}$ & $\begin{array}{l}-0.153 \\
(-0.94)\end{array}$ \\
\hline GROWTH & $\begin{array}{l}0.001 \\
(1.55)\end{array}$ & $\begin{array}{c}0.058^{* *} \\
(2.13)\end{array}$ & $\begin{array}{l}0.001 \\
(0.93)\end{array}$ & $\begin{array}{c}0.082 * * \\
(2.43)\end{array}$ & $\begin{array}{l}-0.002 \\
(-0.83)\end{array}$ & $\begin{array}{l}0.007 \\
(0.10)\end{array}$ \\
\hline FIRST & $\begin{array}{c}-0.011^{* * *} \\
(-6.33)\end{array}$ & $\begin{array}{l}0.028 \\
(0.46)\end{array}$ & $\begin{array}{c}-0.006^{* * *} \\
(-2.98)\end{array}$ & $\begin{array}{l}0.150 * \\
(1.75)\end{array}$ & $\begin{array}{c}-0.018 \text { *** } \\
(-3.60)\end{array}$ & $\begin{array}{c}0.291 \text { * } \\
(1.80)\end{array}$ \\
\hline DUAL & $\begin{array}{l}-0.001 \\
(-1.40)\end{array}$ & $\begin{array}{l}0.032 \\
(1.61)\end{array}$ & $\begin{array}{l}-0.000 \\
(-0.08)\end{array}$ & $\begin{array}{l}0.036 \\
(1.37)\end{array}$ & $\begin{array}{l}-0.002 \\
(-1.33)\end{array}$ & $\begin{array}{l}-0.036 \\
(-0.70)\end{array}$ \\
\hline AGE & $\begin{array}{c}0.006^{* * *} \\
(12.19)\end{array}$ & $\begin{array}{c}0.264^{* * *} \\
(15.68)\end{array}$ & $\begin{array}{c}0.004^{* * *} \\
(6.97)\end{array}$ & $\begin{array}{c}0.261^{* * *} \\
(11.40)\end{array}$ & $\begin{array}{c}0.008^{* * *} \\
(5.76)\end{array}$ & $\begin{array}{c}0.371^{* * *} \\
(8.68)\end{array}$ \\
\hline STATE & $\begin{array}{c}-0.006^{* * *} \\
(-10.12)\end{array}$ & $\begin{array}{l}0.004 \\
(0.20)\end{array}$ & $\begin{array}{c}-0.006^{* * *} \\
(-9.46)\end{array}$ & $\begin{array}{l}0.005 \\
(0.17)\end{array}$ & $\begin{array}{c}-0.007^{* * *} \\
(-4.22)\end{array}$ & $\begin{array}{l}-0.045 \\
(-0.81)\end{array}$ \\
\hline _cons & $\begin{array}{c}-0.014^{* *} \\
(-2.44)\end{array}$ & $\begin{array}{c}9.001 * * * \\
(43.18)\end{array}$ & $\begin{array}{l}0.009 \\
(1.47)\end{array}$ & $\begin{array}{c}8.511^{* * *} \\
(29.69)\end{array}$ & $\begin{array}{l}-0.023 \\
(-1.31)\end{array}$ & $\begin{array}{c}11.195 * * * \\
(19.69)\end{array}$ \\
\hline YEAR & control & control & control & control & control & control \\
\hline INDUSTRY & control & control & control & control & control & control \\
\hline $\begin{array}{c}\mathrm{N} \\
\text { adj. } \mathrm{R}^{2}\end{array}$ & $\begin{array}{c}9472 \\
0.3504\end{array}$ & $\begin{array}{c}9135 \\
0.3955\end{array}$ & $\begin{array}{c}4684 \\
0.2808\end{array}$ & $\begin{array}{c}4531 \\
0.4059\end{array}$ & $\begin{array}{c}1462 \\
0.3778\end{array}$ & $\begin{array}{c}1391 \\
0.4379\end{array}$ \\
\hline
\end{tabular}

Notes: The first row represents the estimated coefficient; the second row represents the $t$-value of significance. $*, * *$, and ${ }^{* * *}$ indicate statistical significance at $p<0.10,0.05$, and 0.01 , respectively.

\subsubsection{The Moderating Effect of Corporate Governance}

Previous studies have found that the level of corporate governance will have a significant impact on the innovation performance of an enterprise [54]. We propose that the level of corporate governance will also have an impact on the relationship between green innovation and a firm's value. The moderating effect of corporate governance may be reflected in the following two aspects: first, a higher level of corporate governance can help alleviate the problem of agency, which can make green innovation technology applicable where it can really enhance the competitive advantage of the enterprise and realize the value-added function. Second, a higher level of corporate governance can convey positive information to the stakeholder, reduce information asymmetry, and improve the transparency of information regarding enterprises, which helps enterprises to obtain external financing at a lower cost [21]. Compared with enterprises with a lower level of corporate governance, the green innovation of enterprises with a higher level of corporate governance can better coordinate the relationship between enterprises and stakeholders, reduce enterprises' financing costs, and improve enterprises' debt financing capabilities. Therefore, we expect that the level of corporate governance has a positive moderating effect on the correlation between green innovation and a firm's value. 
Table 7. The moderating effect of property rights.

\begin{tabular}{|c|c|c|c|c|c|c|}
\hline & $\begin{array}{c}\text { (1) } \\
\text { VALUE } \\
\text { SOE } \\
\text { Full Sample }\end{array}$ & $\begin{array}{c}(2) \\
\text { VALUE } \\
\text { Non-SOE } \\
\text { Full Sample }\end{array}$ & $\begin{array}{c}\text { (3) } \\
\text { VALUE } \\
\text { SOE } \\
\text { Growth Stage }\end{array}$ & $\begin{array}{c}(4) \\
\text { VALUE } \\
\text { Non-SOE } \\
\text { Growth Stage }\end{array}$ & $\begin{array}{c}\text { (5) } \\
\text { VALUE } \\
\text { SOE } \\
\text { Decline Stage }\end{array}$ & $\begin{array}{c}\text { (6) } \\
\text { VALUE } \\
\text { Non-SOE } \\
\text { Decline Stage }\end{array}$ \\
\hline GREEN & $\begin{array}{l}0.025 \\
(1.36)\end{array}$ & $\begin{array}{c}0.044^{* * *} \\
(2.79)\end{array}$ & $\begin{array}{l}0.026 \\
(1.18)\end{array}$ & $\begin{array}{c}0.043 * * \\
(2.24)\end{array}$ & $\begin{array}{l}-0.013 \\
(-0.21)\end{array}$ & $\begin{array}{c}0.065 * * \\
(2.13)\end{array}$ \\
\hline SIZE & $\begin{array}{c}-0.328^{* * *} \\
(-14.50)\end{array}$ & $\begin{array}{c}-0.429 * * * \\
(-16.40)\end{array}$ & $\begin{array}{c}-0.306^{* * *} \\
(-12.49)\end{array}$ & $\begin{array}{c}-0.389 * * * \\
(-14.30)\end{array}$ & $\begin{array}{c}-0.449 * * * \\
(-9.15)\end{array}$ & $\begin{array}{c}-0.574^{* * *} \\
(-8.52)\end{array}$ \\
\hline ROA & $\begin{array}{c}4.628^{* * *} \\
(8.24)\end{array}$ & $\begin{array}{c}5.284^{* * *} \\
(10.95)\end{array}$ & $\begin{array}{c}5.410^{* * *} \\
(5.94)\end{array}$ & $\begin{array}{c}5.375^{* * *} \\
(8.52)\end{array}$ & $\begin{array}{c}4.193^{* * *} \\
(4.13)\end{array}$ & $\begin{array}{c}3.549 * * * \\
(5.90)\end{array}$ \\
\hline LEV & $\begin{array}{c}-0.527^{* * *} \\
(-4.20)\end{array}$ & $\begin{array}{l}0.098 \\
(0.84)\end{array}$ & $\begin{array}{c}-0.488^{* * *} \\
(-2.90)\end{array}$ & $\begin{array}{l}0.048 \\
(0.33)\end{array}$ & $\begin{array}{c}-0.800^{* * *} \\
(-2.86)\end{array}$ & $\begin{array}{l}0.146 \\
(0.70)\end{array}$ \\
\hline GROWTH & $\begin{array}{l}0.063 \\
(1.38)\end{array}$ & $\begin{array}{l}0.039 \\
(1.10)\end{array}$ & $\begin{array}{l}0.093 \\
(1.62)\end{array}$ & $\begin{array}{l}0.059 \\
(1.42)\end{array}$ & $\begin{array}{l}-0.025 \\
(-0.21)\end{array}$ & $\begin{array}{l}0.018 \\
(0.21)\end{array}$ \\
\hline FIRST & $\begin{array}{l}0.002 \\
(0.01)\end{array}$ & $\begin{array}{l}0.078 \\
(0.61)\end{array}$ & $\begin{array}{l}0.048 \\
(0.27)\end{array}$ & $\begin{array}{l}0.190 \\
(1.35)\end{array}$ & $\begin{array}{l}0.486 \\
(1.58)\end{array}$ & $\begin{array}{l}0.235 \\
(0.79)\end{array}$ \\
\hline DUAL & $\begin{array}{l}0.012 \\
(0.22)\end{array}$ & $\begin{array}{l}0.041 \\
(1.20)\end{array}$ & $\begin{array}{l}0.010 \\
(0.16)\end{array}$ & $\begin{array}{l}0.055 \\
(1.39)\end{array}$ & $\begin{array}{l}0.088 \\
(0.67)\end{array}$ & $\begin{array}{l}-0.056 \\
(-0.91)\end{array}$ \\
\hline AGE & $\begin{array}{l}-0.011 \\
(-0.27)\end{array}$ & $\begin{array}{c}0.400 * * * \\
(10.76)\end{array}$ & $\begin{array}{l}-0.018 \\
(-0.31)\end{array}$ & $\begin{array}{c}0.391 * * * \\
(10.31)\end{array}$ & $\begin{array}{l}0.112 \\
(1.41)\end{array}$ & $\begin{array}{c}0.449^{* * *} \\
(4.97)\end{array}$ \\
\hline _cons & $\begin{array}{c}8.555 * * * \\
(19.27)\end{array}$ & $\begin{array}{c}9.841 * * * \\
(19.32)\end{array}$ & $\begin{array}{c}8.555 * * * \\
(15.79)\end{array}$ & $\begin{array}{c}9.055 * * * \\
(16.22)\end{array}$ & $\begin{array}{c}10.197 * * * \\
(11.16)\end{array}$ & $\begin{array}{c}12.441^{* * *} \\
(10.56)\end{array}$ \\
\hline $\begin{array}{c}\text { YEAR } \\
\text { INDUSTRY }\end{array}$ & $\begin{array}{l}\text { control } \\
\text { control }\end{array}$ & $\begin{array}{l}\text { control } \\
\text { control }\end{array}$ & $\begin{array}{l}\text { control } \\
\text { control }\end{array}$ & $\begin{array}{l}\text { control } \\
\text { control }\end{array}$ & $\begin{array}{l}\text { control } \\
\text { control }\end{array}$ & $\begin{array}{l}\text { control } \\
\text { control }\end{array}$ \\
\hline $\begin{array}{c}\mathrm{N} \\
\text { adj. } \mathrm{R}^{2}\end{array}$ & $\begin{array}{c}3914 \\
0.4224\end{array}$ & $\begin{array}{c}5524 \\
0.3872\end{array}$ & $\begin{array}{c}1758 \\
0.4244\end{array}$ & $\begin{array}{c}2863 \\
0.4079\end{array}$ & $\begin{array}{c}633 \\
0.4285\end{array}$ & $\begin{array}{c}840 \\
0.4517\end{array}$ \\
\hline
\end{tabular}

Notes: The first row represents the estimated coefficient; the second row represents the $t$-value of significance. $* *$ and ${ }^{* *}$ indicate statistical significance at $p<0.05$ and 0.01 , respectively.

In order to test the moderating effect of the corporate governance level, we referred to the research of Wu et al. [50] and constructed a corporate governance level index using fourteen variables related to the corporate governance level, including audit committee size, compensation committee size, etc. The larger the index value, the higher the level of corporate governance. Table 8 represents the results of the grouping regression, based on the level of corporate governance. Columns (1), (3) and (5) show the empirical results of samples with a high corporate governance level; columns (2), (4) and (6) show the empirical results of samples with a low corporate governance level. These empirical results show that in samples with high levels of corporate governance, the correlation coefficient between green innovation and firm value was significantly positive; however, in samples with low levels of corporate governance, the correlation coefficient between green innovation and firm value was not significant, indicating that the level of corporate governance has a positive moderating effect on the correlation between green innovation and firm value. Compared with enterprises with low levels of corporate governance, the green innovation of enterprises with high levels of corporate governance will have a more significant impact on a firm's value.

\subsection{Robustness Test}

\subsubsection{Alternative Dependent Variable}

In the previous empirical test, we used VALUE (the enterprise's market value divided by the enterprise's total assets at the end of the period) to measure the value of enterprises. In the robustness test, we used VALUE2 (enterprise market value/(total assets at the end of the period-net intangible assets-net goodwill)) to remeasure the value of the enterprises. The results of the robustness test are shown in Table 9. In the full sample, the correlation coefficient of green innovation and firm value was 0.030 , and it was significantly positive at the $1 \%$ level, indicating that green innovation still has a positive impact on a firm's value after changing the measurement method of the dependent variable. In the growth stage sample and decline stage sample, the correlation coefficients of green innovation and firm value were significantly positive; however, in the maturity stage sample, the coefficient of green innovation is not significant, which is consistent with Hypothesis 2. 
Table 8. The moderating effect of corporate governance.

\begin{tabular}{|c|c|c|c|c|c|c|}
\hline & $\begin{array}{c}\text { (1) } \\
\text { VALUE } \\
\text { High Level } \\
\text { Full Sample }\end{array}$ & $\begin{array}{c}(2) \\
\text { VALUE } \\
\text { Low Level } \\
\text { Full Sample }\end{array}$ & $\begin{array}{c}\text { (3) } \\
\text { VALUE } \\
\text { High Level } \\
\text { Growth Stage }\end{array}$ & $\begin{array}{c}(4) \\
\text { VALUE } \\
\text { Low Level } \\
\text { Growth Stage }\end{array}$ & $\begin{array}{c}\text { (5) } \\
\text { VALUE } \\
\text { High Level } \\
\text { Decline Stage }\end{array}$ & $\begin{array}{c}\text { (6) } \\
\text { VALUE } \\
\text { Low Level } \\
\text { Decline Stage }\end{array}$ \\
\hline GREEN & $\begin{array}{c}0.041^{* * *} \\
(2.83)\end{array}$ & $\begin{array}{l}0.020 \\
(1.03)\end{array}$ & $\begin{array}{c}0.044^{* * *} \\
(2.59)\end{array}$ & $\begin{array}{l}0.022 \\
(0.97)\end{array}$ & $\begin{array}{c}0.084^{* *} \\
(2.43)\end{array}$ & $\begin{array}{l}0.031 \\
(0.74)\end{array}$ \\
\hline SIZE & $\begin{array}{c}-0.311 \text { *** } \\
(-16.45)\end{array}$ & $\begin{array}{c}-0.453^{* * *} \\
(-14.55)\end{array}$ & $\begin{array}{c}-0.296^{* * *} \\
(-14.50)\end{array}$ & $\begin{array}{c}-0.392^{* * *} \\
(-11.83)\end{array}$ & $\begin{array}{c}-0.429 * * * \\
(-9.31)\end{array}$ & $\begin{array}{c}-0.604^{* * *} \\
(-8.40)\end{array}$ \\
\hline ROA & $\begin{array}{c}5.270 * * * \\
(11.77)\end{array}$ & $\begin{array}{c}4.592^{* * *} \\
(8.34)\end{array}$ & $\begin{array}{c}5.539^{* * *} \\
(8.71)\end{array}$ & $\begin{array}{c}5.073 * * * \\
(6.43)\end{array}$ & $\begin{array}{c}4.203^{* * *} \\
(5.49)\end{array}$ & $\begin{array}{c}3.003^{* * *} \\
(3.93)\end{array}$ \\
\hline LEV & $\begin{array}{l}-0.173 * \\
(-1.81)\end{array}$ & $\begin{array}{l}-0.174 \\
(-1.23)\end{array}$ & $\begin{array}{l}-0.103 \\
(-0.76)\end{array}$ & $\begin{array}{c}-0.317 \text { * } \\
(-1.91)\end{array}$ & $\begin{array}{l}-0.340 \\
(-1.65)\end{array}$ & $\begin{array}{l}-0.054 \\
(-0.19)\end{array}$ \\
\hline GROWTH & $\begin{array}{l}0.051 \\
(1.42)\end{array}$ & $\begin{array}{l}0.058 \\
(1.33)\end{array}$ & $\begin{array}{c}0.128^{* * *} \\
(2.79)\end{array}$ & $\begin{array}{l}0.019 \\
(0.38)\end{array}$ & $\begin{array}{l}-0.104 \\
(-1.18)\end{array}$ & $\begin{array}{l}0.185 \\
(1.58)\end{array}$ \\
\hline FIRST & $\begin{array}{l}-0.054 \\
(-0.45)\end{array}$ & $\begin{array}{l}0.186 \\
(1.08)\end{array}$ & $\begin{array}{l}0.002 \\
(0.01)\end{array}$ & $\begin{array}{c}0.439 * * \\
(2.12)\end{array}$ & $\begin{array}{l}0.277 \\
(0.99)\end{array}$ & $\begin{array}{l}0.350 \\
(1.02)\end{array}$ \\
\hline DUAL & $\begin{array}{l}0.007 \\
(0.18)\end{array}$ & $\begin{array}{l}0.048 \\
(1.17)\end{array}$ & $\begin{array}{l}0.033 \\
(0.70)\end{array}$ & $\begin{array}{l}0.047 \\
(1.00)\end{array}$ & $\begin{array}{l}0.013 \\
(0.14)\end{array}$ & $\begin{array}{l}-0.097 \\
(-1.32)\end{array}$ \\
\hline AGE & $\begin{array}{c}0.192^{* * *} \\
(6.79)\end{array}$ & $\begin{array}{c}0.337^{* * *} \\
(6.93)\end{array}$ & $\begin{array}{c}0.227^{* * *} \\
(7.03)\end{array}$ & $\begin{array}{c}0.281^{* * *} \\
(5.03)\end{array}$ & $\begin{array}{c}0.278^{* * *} \\
(3.97)\end{array}$ & $\begin{array}{c}0.445^{* * *} \\
(5.03)\end{array}$ \\
\hline STATE & $\begin{array}{l}0.019 \\
(0.47)\end{array}$ & $\begin{array}{l}0.047 \\
(0.65)\end{array}$ & $\begin{array}{l}-0.008 \\
(-0.17)\end{array}$ & $\begin{array}{l}0.097 \\
(1.00)\end{array}$ & $\begin{array}{l}-0.028 \\
(-0.32)\end{array}$ & $\begin{array}{l}0.053 \\
(0.44)\end{array}$ \\
\hline _cons & $\begin{array}{c}7.901 * * * \\
(20.75)\end{array}$ & $\begin{array}{c}10.437^{* * *} \\
(16.95)\end{array}$ & $\begin{array}{c}7.706^{* * *} \\
(17.62)\end{array}$ & $\begin{array}{c}9.439 * * * \\
(13.68)\end{array}$ & $\begin{array}{c}9.740^{* * *} \\
(11.49)\end{array}$ & $\begin{array}{c}12.740^{* * *} \\
(9.27)\end{array}$ \\
\hline $\begin{array}{c}\text { YEAR } \\
\text { INDUSTRY }\end{array}$ & $\begin{array}{l}\text { control } \\
\text { control }\end{array}$ & $\begin{array}{l}\text { control } \\
\text { control }\end{array}$ & $\begin{array}{l}\text { control } \\
\text { control }\end{array}$ & $\begin{array}{l}\text { control } \\
\text { control }\end{array}$ & $\begin{array}{l}\text { control } \\
\text { control }\end{array}$ & $\begin{array}{l}\text { control } \\
\text { control }\end{array}$ \\
\hline $\begin{array}{c}\mathrm{N} \\
\operatorname{adj} . \mathrm{R}^{2}\end{array}$ & $\begin{array}{c}5678 \\
0.3998\end{array}$ & $\begin{array}{c}3760 \\
0.3902\end{array}$ & $\begin{array}{c}2689 \\
0.4065\end{array}$ & $\begin{array}{c}1932 \\
0.4022\end{array}$ & $\begin{array}{c}843 \\
0.4250\end{array}$ & $\begin{array}{c}630 \\
0.4489\end{array}$ \\
\hline
\end{tabular}

Notes: The first row represents the estimated coefficient; the second row represents the $t$-value of significance.

$* * *$, and $* *$ indicate statistical significance at $p<0.10,0.05$, and 0.01 , respectively.

\subsection{Robustness Test}

\subsubsection{Alternative Dependent Variable}

In the previous empirical test, we used VALUE (the enterprise's market value divided by the enterprise's total assets at the end of the period) to measure the value of enterprises. In the robustness test, we used VALUE2 (enterprise market value/(total assets at the end of the period-net intangible assets-net goodwill)) to remeasure the value of the enterprises. The results of the robustness test are shown in Table 9. In the full sample, the correlation coefficient of green innovation and firm value was 0.030 , and it was significantly positive at the $1 \%$ level, indicating that green innovation still has a positive impact on a firm's value after changing the measurement method of the dependent variable. In the growth stage sample and decline stage sample, the correlation coefficients of green innovation and firm value were significantly positive; however, in the maturity stage sample, the coefficient of green innovation is not significant, which is consistent with Hypothesis 2.

\subsubsection{Two-Stage Least Squares Method (2SLS)}

There may be some missing variables in this empirical test that can affect green innovation and firm value at the same time, which may interfere with the results of this paper. In order to alleviate this endogeneity problem, we also used the two-stage least squares method (2SLS) as a robustness test. We selected the average level of green innovation of other enterprises in the same industry and same year as the instrumental variable (GREEN_mean). The reason for this is that the average level of green innovation of other enterprises in the same industry and the same year may have an impact on the level of green innovation of an individual listed enterprise, but it will not directly affect the firm value of that individual listed enterprise, which finding can satisfy the relevance and exogenous hypothesis of the instrumental variable. Table 10 shows the empirical results of the second stage of a two-stage least squares regression. (The first-stage regression results of the two-stage least squares regression showed that the estimated coefficients of the instrumental variable (GREEN_mean) were always significantly positive at the $1 \%$ level, indicating that the average level of green innovation of other enterprises in the same industry and the same year can affect the level of green innovation of any individual listed enterprise. The results are not reported in this paper.) In the full sample, the estimated 
coefficient of the main explanatory variable GREEN is 0.169 , and it is significantly positive at the $5 \%$ level, indicating that Hypothesis 1 of this paper is robust after controlling the potential endogenous problems. In the growth-stage sample and decline-stage sample, the estimated coefficients of the main explanatory variable GREEN were significantly positive at the 5\% level; however, in the maturity-stage sample, the coefficient of GREEN was not significant, which is consistent with Hypothesis 2.

Table 9. Alternative dependent variables.

\begin{tabular}{|c|c|c|c|c|}
\hline & $\begin{array}{c}\text { (1) } \\
\text { VALUE2 } \\
\text { Full Sample }\end{array}$ & $\begin{array}{c}(2) \\
\text { VALUE2 } \\
\text { Growth Stage }\end{array}$ & $\begin{array}{c}\text { (3) } \\
\text { VALUE2 } \\
\text { Mature Stage }\end{array}$ & $\begin{array}{c}(4) \\
\text { VALUE2 } \\
\text { Decline Stage }\end{array}$ \\
\hline GREEN & $\begin{array}{c}0.030 \text { ** } \\
(2.15)\end{array}$ & $\begin{array}{c}0.034^{* *} \\
(2.15)\end{array}$ & $\begin{array}{l}0.020 \\
(0.89)\end{array}$ & $\begin{array}{c}0.044^{* * *} \\
(2.68)\end{array}$ \\
\hline SIZE & $\begin{array}{c}-0.369 * * * \\
(-18.78)\end{array}$ & $\begin{array}{c}-0.335^{* * * *} \\
(-16.54)\end{array}$ & $\begin{array}{c}-0.362^{* * *} \\
(-13.91)\end{array}$ & $\begin{array}{c}-0.515^{* * *} \\
(-9.83)\end{array}$ \\
\hline ROA & $\begin{array}{c}4.727^{* * *} \\
(10.91)\end{array}$ & $\begin{array}{c}4.981^{* * *} \\
(8.24)\end{array}$ & $\begin{array}{c}5.701^{* * *} \\
(9.01)\end{array}$ & $\begin{array}{c}3.113^{* * *} \\
(5.06)\end{array}$ \\
\hline LEV & $\begin{array}{c}-0.406^{* * *} \\
(-3.90)\end{array}$ & $\begin{array}{c}-0.596^{* * *} \\
(-4.51)\end{array}$ & $\begin{array}{l}-0.269 * \\
(-1.87)\end{array}$ & $\begin{array}{l}-0.329 \\
(-1.32)\end{array}$ \\
\hline GROWTH & $\begin{array}{c}0.221 * * * \\
(6.38)\end{array}$ & $\begin{array}{c}0.257^{* * *} \\
(5.99)\end{array}$ & $\begin{array}{l}0.120 * \\
(1.89)\end{array}$ & $\begin{array}{l}0.123 \\
(1.49)\end{array}$ \\
\hline FIRST & $\begin{array}{l}-0.118 \\
(-1.01)\end{array}$ & $\begin{array}{l}-0.000 \\
(-0.00)\end{array}$ & $\begin{array}{c}-0.337^{* *} \\
(-2.20)\end{array}$ & $\begin{array}{l}0.200 \\
(0.84)\end{array}$ \\
\hline DUAL & $\begin{array}{l}0.052 \\
(1.48)\end{array}$ & $\begin{array}{l}0.067 \\
(1.59)\end{array}$ & $\begin{array}{l}0.039 \\
(0.74)\end{array}$ & $\begin{array}{l}0.012 \\
(0.18)\end{array}$ \\
\hline AGE & $\begin{array}{c}0.281^{* * *} \\
(8.75)\end{array}$ & $\begin{array}{c}0.266^{* * *} \\
(7.53)\end{array}$ & $\begin{array}{c}0.242 * * * \\
(5.52)\end{array}$ & $\begin{array}{c}0.421^{* * * *} \\
(6.14)\end{array}$ \\
\hline STATE & $\begin{array}{l}-0.043 \\
(-1.00)\end{array}$ & $\begin{array}{l}-0.024 \\
(-0.46)\end{array}$ & $\begin{array}{l}-0.010 \\
(-0.18)\end{array}$ & $\begin{array}{l}-0.084 \\
(-1.00)\end{array}$ \\
\hline _cons & $\begin{array}{c}9.126^{* * *} \\
(23.70)\end{array}$ & $\begin{array}{c}8.646^{* * *} \\
(20.53)\end{array}$ & $\begin{array}{c}8.839^{* * *} \\
(17.01)\end{array}$ & $\begin{array}{c}11.480^{* * * *} \\
(12.37)\end{array}$ \\
\hline YEAR & control & control & control & control \\
\hline INDUSTRY & control & control & control & control \\
\hline $\begin{array}{c}\mathrm{N} \\
\operatorname{adj} . \mathrm{R}^{2}\end{array}$ & $\begin{array}{c}9445 \\
0.3856\end{array}$ & $\begin{array}{c}4622 \\
0.4107\end{array}$ & $\begin{array}{c}3348 \\
0.3633\end{array}$ & $\begin{array}{c}1475 \\
0.4385\end{array}$ \\
\hline
\end{tabular}

Notes: The first row represents the estimated coefficient; the second row represents the $t$-value of significance $*, * *$, and ${ }^{* * *}$ indicate statistical significance at $p<0.10,0.05$, and 0.01 , respectively.

\subsubsection{Heckman Test}

This paper focuses on the impact of green innovation on a firm's value, but the selected enterprises' green innovation data has many missing values, which may cause the results of this paper to be affected by self-selection issues. In order to solve the problem of sample self-selection, we adopted the Heckman two-stage test method. In the first stage of the test, a dummy variable (DUMMY) was defined. When the green innovation data in the sample was not missing, DUMMY $=1$, and when the green innovation data in the sample was missing, DUMMY $=0$. Similarly, the average level of green innovation of other enterprises in the same industry and the same year was selected as the instrumental variable (GREEN_mean). In the first stage, DUMMY was used as the explained variable for probit estimation, then the inverse mills ratio (IMR) was obtained. In the second stage, the inverse mills ratio (IMR) was added to the regression model (1). The results of the second stage of the Heckman two-stage test are shown in Table 11. (The first-stage regression results of the Heckman two-stage test showed that the coefficients of GREEN_mean were always significantly positive at the $1 \%$ level, indicating that the sample did have a selfselection problem. The results are not reported in this paper.) In the full sample, the coefficient of GREEN was 0.028 , and it was significantly positive at the $5 \%$ level, indicating that Hypothesis 1 of this paper can still exist after controlling for the potential self-selection problem. In the growth-stage sample and decline-stage sample, the estimated coefficients of 
the main explanatory variable GREEN were significantly positive at the $5 \%$ level; however, in the mature-stage sample, the coefficient of GREEN was not significant, indicating that Hypothesis 2 of this paper can still exist after controlling for the potential self-selection problem.

Table 10. Two-stage least-squares method.

\begin{tabular}{|c|c|c|c|c|}
\hline & $\begin{array}{c}\text { (1) } \\
\text { VALUE } \\
\text { Full Sample }\end{array}$ & $\begin{array}{c}\text { (2) } \\
\text { VALUE } \\
\text { Growth Stage }\end{array}$ & $\begin{array}{c}\text { (3) } \\
\text { VALUE } \\
\text { Mature Stage }\end{array}$ & $\begin{array}{c}\text { (4) } \\
\text { VALUE } \\
\text { Decline Stage }\end{array}$ \\
\hline GREEN & $\begin{array}{c}0.169 * * \\
(2.17)\end{array}$ & $\begin{array}{c}0.188^{* *} \\
(2.30)\end{array}$ & $\begin{array}{l}0.162 \\
(0.95)\end{array}$ & $\begin{array}{c}0.204^{* *} \\
(2.27)\end{array}$ \\
\hline SIZE & $\begin{array}{c}-0.388^{* * *} \\
(-15.23)\end{array}$ & $\begin{array}{c}-0.365^{* * *} \\
(-9.31)\end{array}$ & $\begin{array}{c}-0.391 \text { *** } \\
(-11.27)\end{array}$ & $\begin{array}{c}-0.492 * * * \\
(-8.88)\end{array}$ \\
\hline ROA & $\begin{array}{c}4.917^{* * *} \\
(13.04)\end{array}$ & $\begin{array}{c}5.224^{* * *} \\
(9.88)\end{array}$ & $\begin{array}{c}5.455^{* * *} \\
(9.61)\end{array}$ & $\begin{array}{c}3.693^{* * *} \\
(6.91)\end{array}$ \\
\hline LEV & $\begin{array}{c}-0.265^{* * *} \\
(-2.96)\end{array}$ & $\begin{array}{c}-0.278^{* *} \\
(-2.45)\end{array}$ & $\begin{array}{l}-0.239 * \\
(-1.76)\end{array}$ & $\begin{array}{l}-0.308^{*} \\
(-1.70)\end{array}$ \\
\hline GROWTH & $\begin{array}{l}0.046 \\
(1.62)\end{array}$ & $\begin{array}{c}0.072^{* *} \\
(2.05)\end{array}$ & $\begin{array}{l}0.015 \\
(0.25)\end{array}$ & $\begin{array}{l}-0.015 \\
(-0.22)\end{array}$ \\
\hline FIRST & $\begin{array}{l}0.069 \\
(0.64)\end{array}$ & $\begin{array}{l}0.227 \\
(1.60)\end{array}$ & $\begin{array}{l}-0.199 \\
(-1.41)\end{array}$ & $\begin{array}{l}0.293 \\
(1.39)\end{array}$ \\
\hline DUAL & $\begin{array}{l}0.024 \\
(0.81)\end{array}$ & $\begin{array}{l}0.031 \\
(0.90)\end{array}$ & $\begin{array}{l}0.035 \\
(0.73)\end{array}$ & $\begin{array}{l}-0.037 \\
(-0.68)\end{array}$ \\
\hline AGE & $\begin{array}{c}0.252^{* * *} \\
(8.89)\end{array}$ & $\begin{array}{c}0.249^{* * *} \\
(7.68)\end{array}$ & $\begin{array}{c}0.218^{* * *} \\
(5.32)\end{array}$ & $\begin{array}{c}0.338^{* * *} \\
(5.62)\end{array}$ \\
\hline STATE & $\begin{array}{l}0.010 \\
(0.27)\end{array}$ & $\begin{array}{l}0.011 \\
(0.24)\end{array}$ & $\begin{array}{l}0.040 \\
(0.80)\end{array}$ & $\begin{array}{l}-0.013 \\
(-0.18)\end{array}$ \\
\hline _cons & $\begin{array}{c}9.766^{* * *} \\
(20.58)\end{array}$ & $\begin{array}{c}9.287^{* * *} \\
(12.93)\end{array}$ & $\begin{array}{c}9.817^{* * *} \\
(15.17)\end{array}$ & $\begin{array}{c}11.621^{* * *} \\
(11.54)\end{array}$ \\
\hline $\begin{array}{c}\text { YEAR } \\
\text { INDUSTRY }\end{array}$ & $\begin{array}{l}\text { control } \\
\text { control }\end{array}$ & $\begin{array}{l}\text { control } \\
\text { control }\end{array}$ & $\begin{array}{l}\text { control } \\
\text { control }\end{array}$ & $\begin{array}{l}\text { control } \\
\text { control }\end{array}$ \\
\hline $\begin{array}{c}\mathrm{N} \\
\operatorname{adj} . \mathrm{R}^{2}\end{array}$ & $\begin{array}{c}9438 \\
0.3762\end{array}$ & $\begin{array}{c}4621 \\
0.3838\end{array}$ & $\begin{array}{c}3344 \\
0.3425\end{array}$ & $\begin{array}{c}1473 \\
0.4336\end{array}$ \\
\hline
\end{tabular}

Notes: The first row represents the estimated coefficient; the second row represents the $t$-value of significance. $* * *$, and ${ }^{* * *}$ indicate statistical significance at $p<0.10,0.05$, and 0.01 , respectively.

Table 11. Heckman test.

\begin{tabular}{|c|c|c|c|c|}
\hline & $\begin{array}{c}\text { (1) } \\
\text { VALUE } \\
\text { Full Sample }\end{array}$ & $\begin{array}{c}(2) \\
\text { VALUE } \\
\text { Growth Stage }\end{array}$ & $\begin{array}{c}\text { (3) } \\
\text { VALUE } \\
\text { Mature Stage }\end{array}$ & $\begin{array}{c}\text { (4) } \\
\text { VALUE } \\
\text { Decline Stage }\end{array}$ \\
\hline GREEN & $\begin{array}{c}0.028 * * \\
(2.31)\end{array}$ & $\begin{array}{c}0.034 * * \\
(2.32)\end{array}$ & $\begin{array}{l}0.015 \\
(0.78)\end{array}$ & $\begin{array}{c}0.053 * * \\
(2.18)\end{array}$ \\
\hline IMR & $\begin{array}{c}1.087^{* * *} \\
(4.30)\end{array}$ & $\begin{array}{c}1.105^{* * *} \\
(3.66)\end{array}$ & $\begin{array}{l}0.513 \\
(1.39)\end{array}$ & $\begin{array}{c}1.797^{* * *} \\
(3.72)\end{array}$ \\
\hline SIZE & $\begin{array}{l}-0.103 \\
(-1.82)\end{array}$ & $\begin{array}{l}-0.074 \\
(-1.10)\end{array}$ & $\begin{array}{c}-0.228^{* * *} \\
(-2.68)\end{array}$ & $\begin{array}{l}-0.056 \\
(-0.49)\end{array}$ \\
\hline ROA & $\begin{array}{c}4.844^{* * *} \\
(12.89)\end{array}$ & $\begin{array}{c}5.186 * * * \\
(9.77)\end{array}$ & $\begin{array}{c}5.481^{* * *} \\
(9.74)\end{array}$ & $\begin{array}{c}3.499 * * * \\
(6.57)\end{array}$ \\
\hline LEV & $\begin{array}{l}-0.024 \\
(-0.26)\end{array}$ & $\begin{array}{l}-0.053 \\
(-0.44)\end{array}$ & $\begin{array}{l}-0.053 \\
(-0.38)\end{array}$ & $\begin{array}{l}0.011 \\
(0.06)\end{array}$ \\
\hline GROWTH & $\begin{array}{c}0.115^{* * *} \\
(3.67)\end{array}$ & $\begin{array}{c}0.142 * * * \\
(3.84)\end{array}$ & $\begin{array}{l}0.033 \\
(0.56)\end{array}$ & $\begin{array}{l}0.090 \\
(1.23)\end{array}$ \\
\hline FIRST & $\begin{array}{c}-0.236^{* *} \\
(-2.12)\end{array}$ & $\begin{array}{l}-0.107 \\
(-0.82)\end{array}$ & $\begin{array}{c}-0.354 * * \\
(-2.17)\end{array}$ & $\begin{array}{l}-0.150 \\
(-0.69)\end{array}$ \\
\hline DUAL & $\begin{array}{l}0.019 \\
(0.65)\end{array}$ & $\begin{array}{l}0.028 \\
(0.82)\end{array}$ & $\begin{array}{l}0.023 \\
(0.51)\end{array}$ & $\begin{array}{l}-0.040 \\
(-0.73)\end{array}$ \\
\hline AGE & $\begin{array}{c}0.186^{* * *} \\
(6.51)\end{array}$ & $\begin{array}{c}0.184^{* * *} \\
(5.61)\end{array}$ & $\begin{array}{c}0.171^{* * *} \\
(4.08)\end{array}$ & $\begin{array}{c}0.241^{* * *} \\
(4.03)\end{array}$ \\
\hline STATE & $\begin{array}{l}0.001 \\
(0.03)\end{array}$ & $\begin{array}{l}0.003 \\
(0.06)\end{array}$ & $\begin{array}{l}0.047 \\
(0.97)\end{array}$ & $\begin{array}{l}-0.040 \\
(-0.54)\end{array}$ \\
\hline _cons & $\begin{array}{l}1.515 \\
(0.94)\end{array}$ & $\begin{array}{l}1.071 \\
(0.56)\end{array}$ & $\begin{array}{c}5.063 \text { ** } \\
(2.10)\end{array}$ & $\begin{array}{l}-1.417 \\
(-0.45)\end{array}$ \\
\hline $\begin{array}{c}\text { YEAR } \\
\text { INDUSTRY }\end{array}$ & $\begin{array}{l}\text { control } \\
\text { control }\end{array}$ & $\begin{array}{l}\text { control } \\
\text { control }\end{array}$ & $\begin{array}{l}\text { control } \\
\text { control }\end{array}$ & $\begin{array}{l}\text { control } \\
\text { control }\end{array}$ \\
\hline $\begin{array}{c}\mathrm{N} \\
\text { adj. } \mathrm{R}^{2}\end{array}$ & $\begin{array}{c}9438 \\
0.3947\end{array}$ & $\begin{array}{c}4621 \\
0.4079\end{array}$ & $\begin{array}{c}3344 \\
0.3756\end{array}$ & $\begin{array}{c}1473 \\
0.4405\end{array}$ \\
\hline
\end{tabular}

Notes: The first row represents the estimated coefficient; the second row represents the $t$-value of significance. $*, * *$, and ${ }^{* * *}$ indicate statistical significance at $p<0.10,0.05$, and 0.01 , respectively. 


\section{Conclusions and Policy Implications}

\subsection{Conclusions}

This paper uses Chinese A-share-listed companies as a sample to study whether green innovation has an impact on firm value and how this impact differed at different stages of an enterprise's life cycle. We found that green innovation has a positive impact on firm value, but the degree and the mechanisms of this impact are different at different stages of enterprise life cycles. Compared with enterprises at the mature stage, the green innovation of enterprises at the stages of growth and decline can have a greater impact on a firm's value. Further research shows that sustainable development capabilities and debt-financing costs play a mediating role. For enterprises at the growth stage, green innovation can increase a firm's value by improving the enterprises' sustainable development capabilities and reducing the enterprises' debt-financing costs. For enterprises at the decline stage, although green innovation cannot improve an enterprise's sustainable development capabilities, it can increase the value of an enterprise through reducing the enterprise's debt-financing costs. In addition, we also find that the nature of property rights and the level of corporate governance have moderating effects on the correlation between green innovation and firm value. Compared with state-owned enterprises, green innovation in private enterprises can have a greater impact on increasing a firm's value; compared with the enterprises with a low corporate governance level, green innovation in enterprises with a high corporate governance level can have a greater impact on increasing firm value.

\subsection{Policy Implications}

Several policy implications can be drawn from this study: first, there is no contradiction between environmental protection and the sustainable economic development of enterprises. Enterprises can achieve economic growth while coexisting in harmony with the environment. Green innovation contributes to the increase of a firm's value. The government should continue to encourage enterprises to protect the environment and develop a green economy. At the same time, they should provide certain subsidies or other forms of assistance to promote the sustainable development of the market economy. Second, Chinese enterprises should enhance their green innovation capabilities. However, for enterprises at different stages of their life cycle and enterprises with different property rights, the degree of impact of green innovation on enterprise development is different. Private enterprises and enterprises at the growth and decline stages should realize the positive significance of green innovation to those enterprises and pay more attention to the development of green innovation. Third, enterprises should actively improve their corporate governance and create a better internal and external environment, which can help green innovation play a greater role in increasing firm value.

\section{Limitations and Future Lines of Research}

The results of this paper are encouraging and can cover several research gaps left by previous studies. However, this paper also has some limitations, which need to be improved and supplemented by future research.

First, this paper uses the number of an enterprise's green patent applications to measure the green innovation level of Chinese listed companies. However, green patents have different classification standards. In terms of the type of applicant, green patents can be divided into green patents independently applied for by listed companies and green patents jointly applied for by listed companies and other companies. In terms of the type of patents, green patents can be divided into green patents for invention and green patents for a utility model. Different types of green patents may represent the different green innovation abilities of enterprises. Future research can further distinguish different types of green patents and study the difference in green innovation abilities, as represented by different types of green patents.

Second, using green patents to measure green innovation also has some limitations. On the one hand, some enterprises may have implemented green innovation but have 
not applied for green patents. Using green patents to measure green innovation may lead researchers to underestimate the green innovation abilities of these listed companies. On the other hand, we can only measure the number of green patents but not the quality of those green patents, which might reduce the comparability of green patent value among different enterprises, to a certain extent. Future research can find more appropriate green innovation indicators, which can help to better study the relationship between green innovation and a firm's value.

Third, this study only focuses on the green innovation status of Chinese listed firms. However, the impact of green innovation may be different among different countries. Future research could investigate the value of green innovation internationally and compare the impact of green innovation among different countries.

Author Contributions: Conceptualization, D.D. and Y.X.; methodology, Y.X.; formal analysis, Y.X.; investigation, D.D. and Y.X.; resources, D.D. and Y.X.; writing-original draft preparation, D.D. and Y.X.; writing-review and editing, D.D. and Y.X.; visualization, D.D. and Y.X.; supervision, D.D.; project administration, D.D. and Y.X.; funding acquisition, Y.X. All authors have read and agreed to the published version of the manuscript.

Funding: This research was funded by the Fundamental Research Funds for the Central Universities, and the Research Funds of Renmin University of China (No. 21XNH139).

Institutional Review Board Statement: Not applicable.

Informed Consent Statement: Not applicable.

Data Availability Statement: The datasets used and/or analyzed during the current study are available from the corresponding author on reasonable request.

Acknowledgments: We are grateful to all the funding agencies, the editors and the anonymous reviewers for valuable comments and suggestions.

Conflicts of Interest: The authors declare no conflict of interest.

\section{Appendix A}

Table A1. Detailed composition of CGI. Reprinted with permission from ref. [50], 2020, Wu, W.; Peng, F.; Shan, Y.G.; Zhang, L.

\begin{tabular}{|c|c|}
\hline Variable & Definition \\
\hline CGI & Corporate governance index (CGI) is the sum of 14 internal governance factors. \\
\hline (1) Audit Committee Size & $\begin{array}{l}\text { An indicator variable equal to } 1 \text { if the size of a firm's audit committee is larger than the } \\
\text { median of the sample, } 0 \text { otherwise. }\end{array}$ \\
\hline (2) Compensation Committee Size & $\begin{array}{c}\text { An indicator variable equal to } 1 \text { if the size of a firm's compensation committee is larger } \\
\text { than the median of the sample, } 0 \text { otherwise. }\end{array}$ \\
\hline (3) Nomination Committee Size & $\begin{array}{c}\text { An indicator variable equal to } 1 \text { if the size of a firm's nomination committee is larger } \\
\text { than the median of the sample, } 0 \text { otherwise. }\end{array}$ \\
\hline (4) Strategy Committee Size & $\begin{array}{l}\text { An indicator variable equal to } 1 \text { if the size of a firm's strategy committee is larger than } \\
\text { the median of the sample, } 0 \text { otherwise. }\end{array}$ \\
\hline (5) Independence of Audit Committee & $\begin{array}{l}\text { An indicator variable equal to } 1 \text { if the percentage of a firm's independent directors on } \\
\text { the audit committee is larger than the median of the sample, } 0 \text { otherwise. }\end{array}$ \\
\hline (6) Independence of Compensation Committee & $\begin{array}{l}\text { An indicator variable equal to } 1 \text { if the percentage of a firm's independent directors on } \\
\text { the compensation committee is larger than the median of the sample, } 0 \text { otherwise. }\end{array}$ \\
\hline (7) Independence of Nomination Committee & $\begin{array}{l}\text { An indicator variable equal to } 1 \text { if the percentage of a firm's independent directors on } \\
\text { the nomination committee is larger than the median of the sample, } 0 \text { otherwise. }\end{array}$ \\
\hline (8) Independence of Strategy Committee & $\begin{array}{l}\text { An indicator variable equal to } 1 \text { if the percentage of a firm's independent directors on } \\
\text { the strategy committee is larger than the median of the sample, } 0 \text { otherwise. }\end{array}$ \\
\hline (9) Expertise of Supervisory Board & $\begin{array}{l}\text { An indicator variable equal to } 1 \text { if the number of a firm's committee members with } \\
\text { accounting and finance expertise is larger than the median of the sample, } 0 \text { otherwise. }\end{array}$ \\
\hline (10) Number of Supervisory Board members & $\begin{array}{c}\text { An indicator variable equal to } 1 \text { if the number of a firm's supervisory board members is } \\
\text { larger than the median of the sample, } 0 \text { otherwise. }\end{array}$ \\
\hline (11) Number of Supervisory Board meetings & $\begin{array}{c}\text { An indicator variable equal to } 1 \text { if the number of a firm's supervisory board meetings is } \\
\text { larger than the median of the sample, } 0 \text { otherwise. }\end{array}$ \\
\hline (12) Share ownership of Supervisory Board members & $\begin{array}{l}\text { An indicator variable equal to } 1 \text { if the share ownership of a firm's supervisory board } \\
\text { members is larger than the median of the sample, } 0 \text { otherwise. }\end{array}$ \\
\hline (13) Share ownership of the largest shareholder & $\begin{array}{c}\text { An indicator variable equal to } 1 \text { is the share ownership of a firm's largest shareholder is } \\
\text { larger than the median of the sample, } 0 \text { otherwise. }\end{array}$ \\
\hline (14) Share ownership of the largest and second-largest shareholders & $\begin{array}{l}\text { An indicator variable equal to } 1 \text { is the share ownership of a firm's largest shareholder } \\
\text { and the second-largest shareholder is larger than the median of the sample, } 0 \text { otherwise. }\end{array}$ \\
\hline
\end{tabular}




\section{References}

1. Zhang, K.; Wen, Z. Review and challenges of policies of environmental protection and sustainable development in China. J. Environ. Manag. 2008, 88, 1249-1261. [CrossRef]

2. Xie, X.; Zhu, Q. How Can Green Innovation Solve the Dilemmas of "Harmonious Coexistence"? J. Manag. World 2021, 37, 128-149.

3. Lin, R.-J.; Tan, K.H.; Geng, Y. Market demand, green product innovation, and firm performance: Evidence from Vietnam motorcycle industry. J. Clean. Prod. 2013, 40, 101-107. [CrossRef]

4. Yu, W.; Ramanathan, R.; Nath, P. Environmental pressures and performance: An analysis of the roles of environmental innovation strategy and marketing capability. Technol. Forecast. Soc. Chang. 2017, 117, 160-169. [CrossRef]

5. Jiang, W.; Chai, H.; Shao, J.; Feng, T. Green entrepreneurial orientation for enhancing firm performance: A dynamic capability perspective. J. Clean. Prod. 2018, 198, 1311-1323. [CrossRef]

6. de Azevedo Rezende, L.; Bansi, A.C.; Alves, M.F.R.; Galina, S.V.R. Take your time: Examining when green innovation affects financial performance in multinationals. J. Clean. Prod. 2019, 233, 993-1003. [CrossRef]

7. Zhang, D.; Rong, Z.; Ji, Q. Green innovation and firm performance: Evidence from listed companies in China. Resour. Conserv. Recycl. 2019, 144, 48-55. [CrossRef]

8. Chen, Y.-S.; Lai, S.-B.; Wen, C.-T. The influence of green innovation performance on corporate advantage in Taiwan. J. Bus. Ethics 2006, 67, 331-339. [CrossRef]

9. Huang, J.-W.; Li, Y.-H. Green innovation and performance: The view of organizational capability and social reciprocity. J. Bus. Ethics 2017, 145, 309-324. [CrossRef]

10. Aguilera-Caracuel, J.; Ortiz-de-Mandojana, N. Green innovation and financial performance: An institutional approach. Organ. Environ. 2013, 26, 365-385. [CrossRef]

11. Wang, Q.; Qu, J.; Wang, B.; Wang, P.; Yang, T. Green technology innovation development in China in 1990-2015. Sci. Total Environ. 2019, 696, 134008. [CrossRef] [PubMed]

12. Stucki, T. Which firms benefit from investments in green energy technologies?-The effect of energy costs. Res. Policy 2019, 48, 546-555. [CrossRef]

13. Black, J.A.; Boal, K.B. Strategic resources: Traits, configurations and paths to sustainable competitive advantage. Strateg. Manag. J. 1994, 15, 131-148. [CrossRef]

14. Werker, C. Innovation, market performance, and competition: Lessons from a product life cycle model. Technovation 2003, 23, 281-290. [CrossRef]

15. Bos, J.W.; Economidou, C.; Sanders, M.W. Innovation over the industry life-cycle: Evidence from EU manufacturing. J. Econ. Behav. Organ. 2013, 86, 78-91. [CrossRef]

16. Jensen, M.C.; Meckling, W.H. Theory of the firm: Managerial behavior, agency costs and ownership structure. J. Financ. Econ. 1976, 3, 305-360. [CrossRef]

17. Drakos, A.A.; Bekiris, F.V. Corporate performance, managerial ownership and endogeneity: A simultaneous equations analysis for the Athens stock exchange. Res. Int. Bus. Financ. 2010, 24, 24-38. [CrossRef]

18. Hu, H.W.; Tam, O.K.; Tan, M.G.-S. Internal governance mechanisms and firm performance in China. Asia Pac. J. Manag. 2010, 27, 727-749. [CrossRef]

19. Zheng, G.J.; Lin, D.J.; Lin, B. Controlling shareholders' financial constraints, tunneling and firm value from the perspective of stock pledge. J. Manag. Sci. China 2014, 17, 72-87.

20. He, Y.; Zhang, D.W. Research on Managerial Traits, Debt Financing and Firm Value. Account. Res. 2015, 65-77. [CrossRef]

21. Zhang, L.M.; Li, Y. Going-Concern Opinions, Corporate Governance and Firm Value: Evidence Based on Financial Distressed Companies. Audit. Econ. Res. 2017, 32, 13-23.

22. Jin, Y.; Jiang, Y.S.; Xi, Y. Venture capital, innovation investment and corporate value-Adding. Sci. Res. Manag. 2016, $37,59-67$.

23. Agustia, D.; Sawarjuwono, T.; Dianawati, W. The mediating effect of environmental management accounting on green innovationFirm value relationship. Int. J. Energy Econ. Policy 2019, 9, 299-306.

24. Belenzon, S.; Patacconi, A. Innovation and firm value: An investigation of the changing role of patents, 1985-2007. Res. Policy 2013, 42, 1496-1510. [CrossRef]

25. García-Piqueres, G.; García-Ramos, R. Is the corporate social responsibility-innovation link homogeneous? Looking for sustainable innovation in the Spanish context. Corp. Soc. Responsib. Environ. Manag. 2020, 27, 803-814. [CrossRef]

26. Li, H.Y. Research on Managerial Traits, Innovation and Firm Value. Econ. Probl. 2017, 91-97. [CrossRef]

27. Valdez-Juárez, L.E.; García-Pérez-de-Lema, D.; Maldonado-Guzmán, G. ICT and KM, Drivers of Innovation and Profitability in SMEs. J. Inf. Knowl. Manag. 2018, 17, 1850007. [CrossRef]

28. Santos-Jaén, J.M.; Madrid-Guijarro, A.; García-Pérez-de-Lema, D. The impact of corporate social responsibility on innovation in small and medium-sized enterprises: The mediating role of debt terms and human capital. Corp. Soc. Responsib. Environ. Manag. 2021, 28, 1200-1215. [CrossRef]

29. Gallardo-Vázquez, D.; Valdez-Juárez, L.E.; Castuera-Díaz, Á.M. Corporate social responsibility as an antecedent of innovation, reputation, performance, and competitive success: A multiple mediation analysis. Sustainability 2019, 11, 5614. [CrossRef]

30. Palacios-Manzano, M.; León-Gomez, A.; Santos-Jaén, J.M. Corporate Social Responsibility as a Vehicle for Ensuring the Survival of Construction SMEs. The Mediating Role of Job Satisfaction and Innovation. IEEE Trans. Eng. Manag. 2021, 1-14. [CrossRef]

31. Yang, J.; Liu, Q.H.; Shi, J.J. The value of corporate green innovation strategy. Sci. Res. Manag. 2015, 36, 18-25. 
32. Wang, X.; Hu, G. Green Innovation, Corporate Reputation and Earnings Information Content. J. Beijing Technol. Bus. Univ. 2020, $35,50-63$.

33. Fernando, Y.; Jabbour, C.J.C.; Wah, W.X. Pursuing green growth in technology firms through the connections between environmental innovation and sustainable business performance: Does service capability matter? Resour. Conserv. Recycl. 2019, 141, 8-20. [CrossRef]

34. Hojnik, J.; Ruzzier, M. The driving forces of process eco-innovation and its impact on performance: Insights from Slovenia. J. Clean. Prod. 2016, 133, 812-825. [CrossRef]

35. Xie, X.; Huo, J.; Zou, H. Green process innovation, green product innovation, and corporate financial performance: A content analysis method. J. Bus. Res. 2019, 101, 697-706. [CrossRef]

36. Zhan, L.; Wang, Y. Management Incentive, over-investment and Firm Values. J. Nankai Bus. Rev. 2013, 16 , 36-46.

37. Zhu, Q.; Sarkis, J.; Lai, K. Green supply chain management innovation diffusion and its relationship to organizational improvement: An ecological modernization perspective. J. Eng. Technol. Manag. 2012, 29, 168-185. [CrossRef]

38. Wu, Z.; Ma, Y. Research on Financing Constraints, Innovation Inputs and Values of Nationalized Enterprise. Sci. Technol. Prog. Policy 2019, 36, 102-109.

39. Wang, Q.; Xu, X. Research on the Value-Creation Mechanism of Corporate Social Responsibility and Its Empirical Test Based on the Stakeholder Theory and Life Cycle Stage Theory. China Soft Sci. 2016, 2, 179-192.

40. Huang, H.; Zhai, S.; Chen, J. Corporate Life Cycle, Financing Methods and Financing Constraints Based on the Moderating Effect Research of Investor Sentiment. J. Financ. Res. 2016, 433, 96-112.

41. Tang, Y.; Song, P.; Tang, G. Life Cycle, Debt Financing and Performance of Enterprises: Empirical Evidence from Listed Manufacturing Companies in China. Collect. Essays Financ. Econ. 2014, 49-56. [CrossRef]

42. Dickinson, V. Cash flow patterns as a proxy for firm life cycle. Account. Rev. 2011, 86, 1969-1994. [CrossRef]

43. Hou, Q.; Song, L.; Jiang, Y. Managerial Behavior, Corporate Life Cycle and Non-efficiency Investment. Account. Res. 2017, 3, 61-69.

44. Yang, X.; Peng, C.; Yao, A. Management capability, internal control and corporate sustainability. Audit. Res. 2018, 34, 121-128.

45. Jin, S. Debt Heterogeneity, Nature of Property Right and Enterprises' Sustainable Development. J. Shanxi Univ. Financ. Econ. 2019, $41,67-84$.

46. Pittman, J.A.; Fortin, S. Auditor choice and the cost of debt capital for newly public firms. J. Account. Econ. 2004, 37, 113-136. [CrossRef]

47. Zhou, K.; Ma, Z.; Wu, L. Managerial Academic Experience and Cost of Debt. Econ. Res. J. 2017, 52, $169-183$.

48. Jia, X.; Liu, Y.; Liao, Y. Stakeholders Pressure, Corporate Social Responsibility, and Firm Value. Chin. J. Manag. 2016, 13, 267-274.

49. Wen, Z.; Zhang, L.; Hou, J.; Liu, H. Testing and application of the mediation effects. Acta Psychol. Sin. 2004, 36, 614-620.

50. Wu, W.; Peng, F.; Shan, Y.G.; Zhang, L. Litigation risk and firm performance: The effect of internal and external corporate governance. Corp. Gov. Int. Rev. 2020, 28, 210-239. [CrossRef]

51. Musso, P.; Schiavo, S. The impact of financial constraints on firm survival and growth. J. Evol. Econ. 2008, 18, 135-149. [CrossRef]

52. Deng, F.; Li, Y. Managerial Ability, Ownership and Innovation Investment-Empirical Evidence Based on High-tech Listed Companies. J. Ind. Technol. Econ. 2019, 38, 19-26.

53. Deng, C.; Sun, J. QFII shareholding, property right nature and enterprise financing constraints. J. Manag. World 2014, $180-181$. [CrossRef]

54. Lu, T.; Dang, Y. Corporate governance and innovation: Differences among industry categories. Econ. Res. J. 2014, 49, 115-128. 